\title{
Isotope modeling of nitric acid formation in the atmosphere using ISO-RACM: testing the importance of NO oxidation, heterogeneous reactions, and trace gas chemistry
}

\section{G. Michalski and F. Xu}

Department of Chemistry, Earth and Atmospheric Sciences, Purdue University 550 Stadium Mall Dr. West Lafayette, West Lafayette, IN, USA

Received: 14 January 2010 - Accepted: 9 February 2010 - Published: 11 March 2010

Correspondence to: G. Michalski (gmichals@purdue.edu)

Published by Copernicus Publications on behalf of the European Geosciences Union.

6829

\begin{abstract}
Here we present ISO-RACM, an isotope mass balance model that utilizes the Regional Atmospheric Chemistry Mechanism to predict $\Delta^{17} \mathrm{O}$ values in atmospheric nitrate. A large number of simulations were carried out that varied atmospheric parameters that 5 are important in altering the magnitude and range of $\Delta^{17} \mathrm{O}$ values generated in photochemically produce nitrate. These parameters included temperature, relative humidity, actinic flux, aerosol surface area and chemical speciation, and three different $\mathrm{N}_{2} \mathrm{O}_{5}$ uptake parameterizations. Trace gas mixing ratios were also varied including $\mathrm{CH}_{4}, \mathrm{CO}$, $\mathrm{NO}_{\mathrm{x}}, \mathrm{O}_{3}$, volatile organic compounds and biogenic organic compounds. The model 10 predicts that there are seasonal, latitudinal and diurnal variations in $\Delta^{17} \mathrm{O}$ values due to changes in actinic flux with lower values corresponding to higher actinic fluxes. There was also a minor positive correlation between higher $\Delta^{17} \mathrm{O}$ values and increased temperature. There were distinct differences in $\Delta^{17} \mathrm{O}$ depending on which $\mathrm{N}_{2} \mathrm{O}_{5}$ parameterization was used, mostly the result of changing relative humidity being a factor in 15 two of the parameterization schemes. Changing $\mathrm{CO}$ and $\mathrm{CH}_{4}$ mixing ratios had negligible impact on $\Delta^{17} \mathrm{O}$ values but significant variation in magnitude and range were predicted with $\mathrm{NO}_{\mathrm{x}}, \mathrm{O}_{3}$, and organic loading. High $\mathrm{NO}_{\mathrm{x}}$ and $\mathrm{O}_{3}$ generated high $\Delta^{17} \mathrm{O}$ with a narrow (10\%) range, while high organics led to low $\Delta^{17} \mathrm{O}$ values and a wider range of possible values. Implications for using $\Delta^{17} \mathrm{O}$ to evaluate $\mathrm{NO}_{x}-\mathrm{NO}_{y}$ chemistry and aerosol formation processes are discussed, as is needed future research.
\end{abstract}

\section{Introduction}

The production of atmospheric nitrate $\left(\mathrm{NO}_{3}^{-}\right.$atm $\left.=\mathrm{HNO}_{3(\mathrm{~g})}+\mathrm{NO}_{3_{(\mathrm{aqq})}^{-}}+\mathrm{NO}_{3_{(\mathrm{s})}^{-}}^{-}\right)$is important in a number of atmospheric and biogeochemical systems. As a strong acid, $\mathrm{HNO}_{3}$ is a significant and increasing component in acid rain, which has seen a resurgence 25 in regions where emission controls remain lax (Rodhe et al., 2002; Dentener et al., 2006). Aerosol nitrate loading is expected to increase as nitrogen oxide $\left(\mathrm{NO}_{\mathrm{x}}\right)$ emis- 
sions associated with human activities continues to grow (Galloway, 1995; Galloway et al., 2004). This increase in aerosol loading has implications for human health since nitrate aerosols are often associated with urban settings and inhalations of particulate matter has been linked to respiratory distress and increased mortality in susceptible

5 populations (Samet et al., 2000; Schwartz and Neas, 2000). Aerosols are also linked to climatic change through direct and indirect radiative forcing (Hansen et al., 2005; Myhre, 2009; Lohmann and Lesins, 2002; Haywood and Boucher, 2000) and nitrate aerosols are projected to become increasingly important in the climate system ( $\mathrm{Li}$ et al., 2009; Bauer et al., 2007). $\mathrm{NO}_{3}^{-}$atm is also a nutrient, and its deposition (wet and

10 dry) can impact ecosystem function (Magill et al., 2004; Fenn et al., 2003; Paerl et al., 2001), initiating carbon uptake in some systems (Bedison and Mcneil, 2009) and retarding carbon storage in others (Scheuner and Makeschin, 2005). High nitrogen deposition can also lead to shifts in biodiversity, declines in forest health, and coastal eutrophication (Magill et al., 2004; Fenn et al., 2003; Paerl et al., 2001). Finally, $\mathrm{NO}_{3}^{-}$atm is

15 incorporated into snow, that in Greenland and Antarctica forms ice sheets and provides a long term ( $\sim 500000 \mathrm{ybp})$ record of variations in $\mathrm{NO}_{3}^{-}$atm concentrations (Hastings et al., 2004; Gladysheva et al., 2003; Delmas, 1998). To date, however, variations in ice core nitrate concentrations (pre-anthroprocene) have yet to be linked to any specific shifts in the global nitrogen cycle over time. Such information would be vital for assessing linkages between the global nitrogen cycle and the carbon cycle and climate system. Therefore, understanding how $\mathrm{NO}_{3}^{-}$atm is formed in the atmosphere and how its concentration (and formation) vary over time and space, is crucial for understanding a number of important environmental systems. In addition being able to trace the biogeochemical fate of post depositional $\mathrm{NO}_{3}^{-}$atm can provide insights into the linkage between the atmospheric and terrestrial $\mathrm{N}$ cycles.

Stable isotopes can play an important role in understanding nitrogen cycling in the atmosphere including the importance of $\mathrm{NO}_{3}^{-}$atm formation pathways. Here we present a photochemical box model sensitivity study that examines how oxygen isotope anomalies are generated during $\mathrm{NO}_{3}^{-}$atm production. The model utilizes kinetic mechanisms

6831

that trace nitric acid formation in the troposphere and an oxygen isotope transfer mechanism involving oxygen atom transfer between ozone and oxides of nitrogen. The objective is to evaluate how different combinations of atmospheric conditions, such as $\mathrm{NO}_{x}$ and organic compound concentrations, relative humidity $(\mathrm{RH})$, or hours of day 5 light, might shift $\mathrm{NO}_{3}^{-}$atm production pathways. These shifts should then be reflected in the $\Delta^{17} \mathrm{O}$ anomaly that is known to exist in $\mathrm{NO}_{3}^{-}$atm (see below). The predictions made by the model will eventually be used to select sampling sites where observations of $\Delta^{17} \mathrm{O}$ values in $\mathrm{NO}_{3}^{-}$atm will be used to test the model assumptions and assess its predictive capabilities. In turn, such a model could help test hypothesis regarding ${ }_{10} \mathrm{~N}_{2} \mathrm{O}_{5}$ uptake and be used to interpret $\Delta^{17} \mathrm{O}$ anomalies in ice cores, aerosols, soils, and precipitation.

\subsection{Mechanisms of $\mathrm{NO}_{3}^{-}$atm formation}

$\mathrm{NO}_{3}^{-}$atm is formed by the oxidation of $\mathrm{NO}_{x}\left(\mathrm{NO}+\mathrm{NO}_{2}\right)$ by several different chemical mechanisms. It is initiated when nitric oxide is oxidized to $\mathrm{NO}_{2}$ by ozone or peroxy 15 radicals (Seinfeld and Pandis, 1998; Finlayson-Pitts and Pitts Jr., 2000).

$$
\begin{aligned}
& \mathrm{NO}+\mathrm{O}_{3} \longrightarrow \mathrm{NO}_{2}+\mathrm{O}_{2} \\
& \mathrm{NO}+\mathrm{HO}_{2}(\mathrm{ROO}) \longrightarrow \mathrm{NO}_{2}+\mathrm{OH}(\mathrm{R})
\end{aligned}
$$

Here we can define an oxidation parameter $\alpha$, which is the \% of NO oxidized by ozone relative to peroxy radicals: $\alpha=\mathrm{R} 1 /(\mathrm{R} 1+\Sigma \mathrm{R} 2$ 's). The term $\Sigma \mathrm{R} 2$ arises because a number of organo-peroxy radicals are capable of oxidizing $\mathrm{NO}$ to $\mathrm{NO}_{2} . \mathrm{NO}_{2}$ can then react with $\mathrm{OH}$ radicals in a 3-body reaction to generate nitric acid.

$\mathrm{NO}_{2}+\mathrm{OH}+\mathrm{M} \longrightarrow \mathrm{HNO}_{3}+\mathrm{M}=\beta$

$\mathrm{NO}_{2}$ can be oxidized further by ozone generating the nitrate radical. The nitrate radical can go on to extract hydrogen atoms from volatile organic compounds (VOC) such 25 as non-methane hydrocarbons (Atkinson, 2000) and biogenic VOC such as isoprene 
(Perring et al., 2009; Horowitz et al., 2007) and di-methylsulfide (DMS) (Stark et al., 2007; Yvon et al., 1996).

$$
\begin{aligned}
& \mathrm{NO}_{2}+\mathrm{O}_{3} \longrightarrow \mathrm{NO}_{3}+\mathrm{O}_{2} \\
& \mathrm{NO}_{3}+\mathrm{VOC} \longrightarrow \mathrm{HNO}_{3}+\mathrm{R}=\chi
\end{aligned}
$$

5 Since $\mathrm{NO}_{3}$ undergoes photolysis at wavelengths in the visible range, its daytime lifetime is short $(\sim 3 \mathrm{~s})$ so this reaction only becomes important at night. Also at night, $\mathrm{NO}_{3}$ can recombine with $\mathrm{NO}_{2}$ to form $\mathrm{N}_{2} \mathrm{O}_{5}$, which is in equilibrium by thermal decomposition.

$$
\mathrm{NO}_{2}+\mathrm{NO}_{3} \leftarrow \rightarrow \mathrm{N}_{2} \mathrm{O}_{5}
$$

$\mathrm{N}_{2} \mathrm{O}_{5}$, nitric acid anhydride, can react with gas phase water to form nitric acid. How10 ever, this reaction is relatively slow and is not thought to be significant under tropospheric conditions (Tuazon et al., 1983; Wahner et al., 1998). Wetted aerosol surfaces, on the other hand, have a catalytic effect and $\mathrm{N}_{2} \mathrm{O}_{5}$ can readily hydrolyze on these surfaces to form $\mathrm{HNO}_{3}$ (Hallquist et al., 2000; Mentel et al., 1999; Mozurkewich and Calvert, 1988).

$15 \quad \mathrm{~N}_{2} \mathrm{O}_{5}\left(\right.$ aerosol $\left./ \mathrm{H}_{2} \mathrm{O}\right) \longrightarrow 2 \mathrm{HNO}_{3}=\varepsilon$

Recently, there has been a significant amount of controversy over what role $\mathrm{N}_{2} \mathrm{O}_{5}$ hydrolysis plays in controlling nighttime $\mathrm{NO}_{x} / \mathrm{NO}_{y}$ concentrations (Brown et al., 2003, 2006). In situ data suggests that $\mathrm{N}_{2} \mathrm{O}_{5}$ uptake on aerosols seems to be a function of aerosol type (sulfate versus organic) and whether they are internally mixed (Brown et

20 al., 2006), but these results are at odds with laboratory studies that have experimentally determined $\mathrm{N}_{2} \mathrm{O}_{5}$ uptake coefficients (Mentel et al., 1999; Mozurkewich and Calvert, 1988; Wahner et al., 1998). Since this reaction is key in titrating nitrogen oxides from the atmosphere, which in turn controls daytime oxidant loads, this gap in our knowledge about $\mathrm{NO}_{x} / \mathrm{NO}_{y}$ cycling is significant.

6833

\subsection{Oxygen isotope transfer model description}

Direct modeling of isotope partitioning into atmospheric reactive species such as $\mathrm{NO}_{\mathrm{x}}$ and $\mathrm{NO}_{3}^{-}$atm is difficult. To do so would require knowing the kinetic and equilibrium fractionation factors (isotopologue rate constants), either by experimental or theoret-

5 ical determination. While equilibrium fractionation factors have been calculated for small stable molecules (Urey, 1947), they have not been evaluated for larger molecules (i.e. $\mathrm{N}_{2} \mathrm{O}_{5}$ ) and radicals. For kinetic isotope effects (KIE) the situation is even less favorable. Relatively few atmospherically relevant KIE's have been experimentally determined and comparisons between experimental and theoretical results often lead to

10 different values, sometimes with opposite signs. In addition, the influence of isotopic variation in different sources that lead to $\mathrm{NO}_{3}^{-}$atm, such as different $\delta^{15} \mathrm{~N}$ values in $\mathrm{NO}_{\mathrm{x}}$ sources or $\delta^{18} \mathrm{O}$ shifts in tropospheric water vapor, adds to the complexity. These difficulties have resulted in only qualitative, generalized evaluations of the mechanisms that control isotope variations $\left(\delta^{15} \mathrm{~N}, \delta^{18} \mathrm{O}\right)$ in $\mathrm{NO}_{\mathrm{y}}$ (Freyer, 1991).

${ }_{15}$ Modeling ${ }^{17} \mathrm{O}$ anomalies, often referred to mass independent effects, has distinct advantages over traditional isotopes fractionations (Lyons, 2001; Michalski et al., 2003). Primarily, only a handful of reactions are known to generate $\delta^{17} \mathrm{O}$ values that do not obey the $\delta^{17} \mathrm{O}=.52 \delta^{18} \mathrm{O}$ mass dependence rule of isotope effects (Thiemens, 2005). Deviations from this rule, the ${ }^{17} \mathrm{O}$ excess, are quantified by $\Delta^{17} \mathrm{O}=\delta^{17} \mathrm{O}-.52 \delta^{18} \mathrm{O}$ 20 (Miller, 2002). The most well known system where $\Delta^{17} \mathrm{O}$ values are generated using reactants that are mass dependent (e.g. the mass independent fractionation - MIF) is during the formation of ozone (Thiemens and Heidenreich III, 1983; Thiemens and Jackson, 1987). While MIF's have been observed in CO (Rockmann et al., 1998; Bhattacharya and Thiemens, 1989), $\mathrm{CO}_{2}$ (Bhattacharya et al., 2000), and $\mathrm{HO}_{\mathrm{x}}$ (Savarino

25 and Thiemens, 1999), the effect is typically much smaller than that observed in ozone and they are often generated via UV dissociation reactions which are trivial in the lower troposphere. Therefore from a tropospheric chemistry perspective, MIF is believed to occur during the production of tropospheric ozone. 
Once $\Delta^{17} \mathrm{O}$ values are generated in ozone (by MIF) they are propagated through to other reactive species by mass balance (Lyons, 2001; Michalski et al., 2003; Alexander et al., 2005). This is the current hypothesis for the origin of $\Delta^{17} \mathrm{O}$ values that have been observed in nitrate (Michalski et al., 2003) and sulfate (Alexander et al., 2005)

5 aerosols, and in tropospheric $\mathrm{H}_{2} \mathrm{O}_{2}$ (Savarino and Thiemens, 1999). This mass balance mechanism can be formulated by

$\Delta^{17} \mathrm{O}\left(\mathrm{NO}_{3_{\mathrm{atm}}^{-}}\right) / d t=\Sigma \mathrm{P}_{(\mathrm{NO}) \mathrm{i}} \cdot \Delta^{17} \mathrm{O}_{\left(\mathrm{NO}_{3}\right) \mathrm{i}}-\Sigma \mathrm{L}_{\left(\mathrm{NO}_{3}\right) \mathrm{j}} \cdot \Delta^{17} \mathrm{O}_{\left(\mathrm{NO}_{3}\right) \mathrm{j}}$

where $\Delta^{17} \mathrm{O}\left(\mathrm{NO}_{3}^{-}\right)$is the ${ }^{17} \mathrm{O}$ excess observed in compound $\mathrm{NO}_{3}^{-} ; \mathrm{P}_{(\mathrm{NO}) \mathrm{i}}$ is the production of nitrate through reaction pathway $\mathrm{i}$ and $\Delta^{17} \mathrm{O}_{(\mathrm{NO}) \mathrm{i}}$ is the $\Delta^{17} \mathrm{O}$ value associated

10 with that pathway. $\mathrm{L}_{(\mathrm{NO}) \mathrm{j})}$ is the analogous terms for the loss process (j) of nitrate. For $\mathrm{NO}_{3}^{-}$atm the main loss processes in the lower troposphere are removal by dry and wet deposition, processes that should have minor mass dependent isotopic effects (i.e. $\Delta^{17} \mathrm{O}=0$ ) so that the $\Delta^{17} \mathrm{O}_{\mathrm{xj}}$ terms become zero and $\Delta \Delta^{17} \mathrm{O}_{\mathrm{x}}=\Sigma \mathrm{P}_{\mathrm{xi}} \cdot \Delta^{17} \mathrm{O}_{\mathrm{xi}}$. In this sense, based on our current understanding, tropospheric production pathways control

15 the $\Delta^{17} \mathrm{O}$ of compounds such as nitrate. This assumption is not true for multidimensional modeling where the loss terms play an important role. For example, if an urban region, with high nitrate production, advects this nitrate to an adjacent, pristine site (cell/box) where production is trivial, the urban signal would mask pristine production from Eq. (1). If removal terms in the urban box were high, say by rainout via an intense 20 storm, then the urban nitrate $\Delta^{17} \mathrm{O}$ signal would not manifest itself in the pristine cell. The present model is zero dimensional (no fluxes) so only the production terms need to be considered.

\section{Methods: $\Delta^{17} \mathrm{O}$ mass balance model}

The $\Delta^{17} \mathrm{O}$ mass balance approach follows previous work that suggests ozone oxidation 25 of $\mathrm{NO}_{\mathrm{x}}$ to higher oxidation states $\left(\mathrm{NO}_{\mathrm{y}}\right)$ is the main transfer mechanism for generating 6835

positive $\Delta^{17} \mathrm{O}$ values in $\mathrm{NO}_{3}^{-}$atm (Savarino et al., 2008; Michalski et al., 2003; Lyons, 2001). The transfer of one oxygen atom from ozone to NO by Reaction (R1) is followed by an assumed mass dependent photolysis of $\mathrm{NO}_{2}$, then re-oxidation of $\mathrm{NO}$ by ozone, ultimately leads to $\mathrm{NO}_{2}$ coming into near isotopic equilibrium with ozone as $\mathrm{NO}_{\mathrm{x}}$ 5 reached photochemical steady state. This equilibrium is upset by oxidation of $\mathrm{NO}$ by Reaction (R2). The $\Delta^{17} \mathrm{O}$ transfer mechanism from ozone to $\mathrm{NO}_{\mathrm{x}}-\mathrm{NO}_{\mathrm{y}}$ can then be formulated as (using shorthand ${ }^{\Delta} X=\Delta{ }^{17} O$ value of compound $X$ )

$$
\begin{aligned}
&{ }^{\Delta} \mathrm{NO}_{2}=\alpha^{\Delta} \mathrm{O}_{3} \\
&{ }_{10} \mathrm{HNO}_{3}(\beta)={ }^{\Delta} \mathrm{O}_{3}(2 \alpha / 3) \\
&{ }^{\Delta} \mathrm{HNO}_{3}(\chi)={ }^{\Delta} \mathrm{O}_{3}(2 \alpha+1) / 3 \\
&{ }^{\Delta} \mathrm{HNO}_{3}(\varepsilon)={ }^{\Delta} \mathrm{O}_{3}(4 \alpha+1) / 6
\end{aligned}
$$

(Michalski et al., 2003) where $\alpha$ is the mole fraction of $\mathrm{NO}$ oxidized by $\mathrm{O}_{3}$, and $\beta, \chi$ and $\varepsilon$ are the mole fractions of $\mathrm{HNO}_{3}$ produced by the Reaction pathways (Reaction R3), (Reaction R5), and (Reaction R7) respectively. Predicting $\Delta^{17} \mathrm{O}$ values in $\mathrm{NO}_{3}^{-}$atm is 15 then a matter of knowing the $\Delta^{17} \mathrm{O}$ value of $\mathrm{O}_{3}$ and calculating the branching ratios $(\alpha$, $\beta, \chi, \varepsilon)$ using a photochemical kinetics model such as RACM (see below). It should be noted that $\alpha$ is not fixed in time but will evolve based on the production time steps and the final $\alpha$ used is summed over all time steps (as in integrating Eq. 1).

\subsection{Uncertainties in the $\Delta^{17} \mathrm{O}$ mass balance model}

There are still a number of uncertainties concerning the specifics of the $\mathrm{NO}_{3}^{-}$atm mass balance approach that need to be acknowledged. The three main uncertainties include possible $\Delta^{17} \mathrm{O}$ transfer from $\mathrm{HO}_{2}$, the $\Delta^{17} \mathrm{O}$ value of tropospheric ozone, and the dynamics of $\mathrm{NO}_{\mathrm{x}}$ oxidation. 
Since some peroxy radicals originate from oxidation reactions with ozone, one must consider whether these compounds would also have $\Delta^{17} \mathrm{O}$ signatures due to oxygen atom transfer. Our assumption is that they are negligible, which is based on the following considerations. Organoperoxy radicals are mainly formed 5 by $\mathrm{H}$ abstraction (via $\mathrm{OH}$ or $\mathrm{NO}_{3}$ ) from organics to form $\mathrm{R}$ followed by recombination with $\mathrm{O}_{2}$ to yield ROO (Finlayson-Pitts and Pitts Jr., 2000). Since the oxygen leading to the peroxide ligand is atmospheric $\mathrm{O}_{2}\left(\Delta^{17} \mathrm{O} \sim-0.3 \%\right.$ ) (Luz et al., 1999) the radical's $\Delta^{17} \mathrm{O}$ value should be $\sim 0 \%$ o. The majority of $\mathrm{HO}_{2}$ is produced by the $\mathrm{H}+\mathrm{O}_{2}$ reaction $\left(k_{\mathrm{H}+\mathrm{O} 2(298)}=1 \times 10^{-12} \mathrm{~cm}^{3}\right.$ molecules $\left.{ }^{-1} \mathrm{~s}^{-1}\right)$, where $\mathrm{H}$

10 is mainly generated by $\mathrm{OH}$ oxidation of $\mathrm{CO}$. The contribution $\mathrm{O}_{3}+\mathrm{OH} \longrightarrow \mathrm{HO}_{2}+\mathrm{O}_{2}$ $\left(k_{\mathrm{O} 3+\mathrm{OH}(298)}=6 \times 10^{-14} \mathrm{~cm}^{3}\right.$ molecules $\left.{ }^{-1} \mathrm{~s}^{-1}\right)$ would be considerably smaller since $\mathrm{CO}$ concentrations are typically higher than $\mathrm{O}_{3}$ and given the larger rate constant for the CO reaction (JPL, 2006). In addition, the possibility of isotopic exchange between $\mathrm{O}_{2}$ and $\mathrm{HO}_{2}$ (Sinha et al., 1987) would likely erase any $\Delta^{17} \mathrm{O}$ transfer from $\mathrm{O}_{3}$. This is

15 analogous to $\mathrm{OH}$ which losses any $\Delta^{17} \mathrm{O}$ signal by exchange with water (Dubey et al., 1997; Lyons, 2001; Michalski et al., 2003) at relative humidity typical of the troposphere. Measurements of $\Delta^{17} \mathrm{O}$ values in $\mathrm{H}_{2} \mathrm{O}_{2}(\sim 2 \%)$ (Savarino and Thiemens, 1999), which is primarily formed by the $\mathrm{HO}_{2}+\mathrm{HO}_{2}$ recombination reaction, supports the notion that $\Delta^{17} \mathrm{O}$ signals in $\mathrm{HO}_{2}$ are small. Therefore in the present model, for sim20 plicity, we assume that $\mathrm{HO}_{\mathrm{x}}$ and $\mathrm{ROO}$. do not transfer any $\Delta^{17} \mathrm{O}$ signature to $\mathrm{NO}_{\mathrm{x}}-\mathrm{NO}_{\mathrm{y}}$.

Temperature and pressure experiments (Thiemens and Jackson, 1990; Morton et al., 1990) suggest that tropospheric $\mathrm{O}_{3}$ should possess $\Delta^{17} \mathrm{O}$ values $\sim 35 \%$, tropospheric measurements, however, show a range of $\mathrm{O}_{3} \Delta^{17} \mathrm{O}$ values that span $6-54 \%$ (Morin et al., 2007; Krankowsky et al., 1995; Johnston and Thiemens, 1997) and do not corre-

25 late with expected temperature and pressure variations. It is not clear whether this is an artifact in the tropospheric $\mathrm{O}_{3}$ data (sampling apparatus) or some unknown isotope effect in the recombination processes or secondary reactions in the troposphere. We believe it is due to the tropospheric sampling approach and this is currently being in-

6837

vestigated. Acknowledging these considerations, in the present work we will choose a $\Delta^{17} \mathrm{O}$ value of ozone based on the experimental pressure and temperature dependent studies. Ozone $\Delta^{17} \mathrm{O}$ values in the model were derived by considering temperature and pressure experimental values. Over deviations of $\pm 10 \mathrm{kPa}$, typical of normal sur5 face pressure variations, the dependence of $\mathrm{O}_{3} \Delta \Delta^{17} \mathrm{O}$ variations on pressure is weak so we have ignored the pressure effect and all simulations were run at $101.5 \mathrm{kPa}$. The $\mathrm{O}_{3} \Delta^{17} \mathrm{O}$ value's dependence on temperature was parameterized using

$\Delta^{17} \mathrm{O}(\%)=10 *[(0.0243 \cdot T(\mathrm{~K})+3.7667)-0.52 \cdot(0.035 \cdot T(\mathrm{~K})+4)]$

(Michalski et al., 2004) based on data from Morton et al. (1990).

$10 \quad$ Finally, the simple mass balance accounting of $\Delta^{17} \mathrm{O}$ transfer from $\mathrm{O}_{3}$ to $\mathrm{NO}_{\mathrm{x}}-\mathrm{NO}_{\mathrm{y}}$ also becomes more complex if ozone's internal isotope distribution, and various $\mathrm{NO}_{\mathrm{x}} \mathrm{-}^{-}$ $\mathrm{NO}_{\mathrm{y}}-\mathrm{O}_{3}$ transition states, are also considered. For example, theoretical and experimental evidence suggests the ${ }^{17} \mathrm{O}$ anomaly is found in the terminal oxygen atom (Bhattacharya et al., 2008; Michalski and Bhattacharya, 2009). If the $\mathrm{NO}+\mathrm{O}_{3}$ reaction pro15 ceeds though a terminal $\mathrm{O}_{3}$ atom transition state (Peiro-Garcia and Nebot-Gil, 2002), the $\Delta^{17}$ O transfer (Savarino et al., 2008) would be $\sim 3 / 2$ the bulk ozone $\Delta^{17}$ O anomaly (terminal mechanism). However, molecular beam studies have suggested that the central oxygen atom in $\mathrm{O}_{3}$ may also be extracted with equal probability (Viswanathan and Raff, 1983; Redpath et al., 1978), so the transfer to $\mathrm{NO}_{2}$ would reflect the bulk

$20 \mathrm{O}_{3} \Delta^{17} \mathrm{O}$ value (bulk mechanism). Likewise, ab initio calculations for the $\mathrm{NO}_{2}+\mathrm{O}_{3}$ reaction (Peiro-Garcia and Nebot-Gil, 2003) suggest a terminal atom extraction but there is no experimental evidence to confirm these calculations. We conclude that there are a number of uncertainties in the mass balance model and that there are no "correct" assumptions, only assumptions. Hopefully, the number of assumptions will be reduced as laboratory, theoretical and field, studies continue and expand. In the present work we will use both the bulk ozone and terminal atom mechanisms when estimating $\mathrm{NO}_{3}^{-}$atm $\Delta^{17} \mathrm{O}$ values and evaluating the results relative to known observations. The correct transfer mechanism will not influence the trends in $\mathrm{NO}_{3}^{-}$atm $\Delta^{17} \mathrm{O}$ values, which 
depend on the branching ratios (i.e. the chemistry), only their magnitude. We discuss the impacts of these assumptions based on our simulation results in the discussion section of this paper.

\subsection{ISO-RACM: linking $\Delta^{17}$ O mass balance to RACM}

5 The Regional Atmospheric Chemistry Mechanism (RACM) model (Stockwell et al., 1997) was utilized for tracing $\mathrm{NO}_{3}^{-}$atm photochemical production pathways because it has a number of advantages over the Yvon et al. (1996) model used previously (Michalski et al., 2003). Its chemical scheme is more sophisticated (238 reactions versus 122), including detailed accounting of anthropogenic hydrocarbon (alkane, alkene, aromat-

10 ics) and biogenic organic (isoprene, $\alpha$-pinene, d-limonene) chemistry that is important in ozone chemistry in urban and forested environments respectively. It has also been extensively validated in chamber and environmental studies by comparing observed and predicted secondary pollutants (Stockwell et al., 1997; Kirchner and Stockwell, 1997), and has been evaluated relative to other chemical mechanisms (Kuhn et al.,

15 1998; Gross and Stockwell, 2003). Also the chemical scheme (and code) is portable into widely used 1-D, 2-D, and 3-D chemical transport models (Gross et al., 2005), which will ease the transition of this $\Delta^{17} \mathrm{O}$ mass balance model into more sophisticated integrated land-surface-chemical transport models in future investigations. The advantage of using the RACM box model in this study, instead of using a more sophisticated

20 3-D model (Alexander et al., 2009), is that we can explore which reactions, conditions, and parameterizations have the most pronounced impact on controlling $\mathrm{NO}_{3}^{-}$atm $\Delta^{17} \mathrm{O}$ values by altering an array of chemical boundary conditions and primary pollutant mixing ratios without requiring enormous amounts of computational resources. Incorporating the isotope mass balance mixing model into RACM, in addition to ongoing work 25 adopting other isotope mechanisms $\left(\delta^{15} \mathrm{~N}\right)$ gives an isotope photochemical model: ISO-RACM.

\subsection{Heterogeneous $\mathrm{N}_{2} \mathrm{O}_{5}$ hydrolysis parameterization in ISO-RACM}

A number of small modifications to ISO-RACM were made to account for additional $\mathrm{NO}_{3}^{-}$atm production pathways. The main addition is a scheme to account for heterogeneous $\mathrm{N}_{2} \mathrm{O}_{5}$ uptake by aerosols. RACM is a gas phase chemical model and lacks an 5 explicit aerosol chemistry scheme. This limitation is typically handled by parameterizing a first order heterogeneous rate constant and treating the $\mathrm{N}_{2} \mathrm{O}_{5}+$ aerosol $\longrightarrow 2 \mathrm{HNO}_{3}$ reaction as a first order gas phase reaction: $k\left[\mathrm{~N}_{2} \mathrm{O}_{5}\right] \longrightarrow 2 \mathrm{HNO}_{3}$ (Riemer et al., 2003). We employed three schemes to parameterize the first order rate constant: one where the uptake coefficient varies with sulfate and nitrate composition, another based of 10 aerosol surface area that varies as a function of relative humidity, and a third that uses multiple experimental data sets to derive fitting parameters for ammoniated sulfate/nitrate aerosols.

The first $\mathrm{N}_{2} \mathrm{O}_{5}$ heterogeneous reaction scheme (scheme $\mathrm{M}$ ) depends on surface area and chemical composition (Riemer et al., 2003; Mentel et al., 1999). The first 15 order rate constant is derived as

$k=1 / 4 c_{\mathrm{N}_{2} \mathrm{O}_{5}} S \gamma_{\mathrm{N}_{2} \mathrm{O}_{5}}$

where $c$ is the mean molecular velocity, $S$ is the aerosol surface area, and $\gamma$ is the aerosol uptake coefficient for $\mathrm{N}_{2} \mathrm{O}_{5}$. The uptake coefficient $\left(\gamma_{\mathrm{N} 2 \mathrm{O} 5}\right)$ is varied as a function of the aerosol mass ratio $(f)$ assuming only sulfate and nitrate are present, and using the individual $\mathrm{N}_{2} \mathrm{O}_{5}$ uptake coefficients for sulfate $\left(\gamma_{1}=.02\right)$ and nitrate $\left(\gamma_{2}=.002\right)$ (Mentel et al., 1999).

$\gamma_{\mathrm{N} 2 \mathrm{O} 5}=f \cdot \gamma_{1}+(1-f) \cdot \gamma_{2} f=\frac{m_{\mathrm{SO}_{4}^{2-}}}{m_{\mathrm{SO}_{4}^{2-}}+m_{\mathrm{NO}_{3}^{-}}}$

The second parameterization (scheme C) was suggested by Chang et al. (1987), which uses relative humidity $(\mathrm{RH})$ as a dependent variable based on the observed 
lifetime of $\mathrm{NO}_{3}$ over a range of $\mathrm{RH}^{\prime}$ (Platt et al., 1984). The rate constant is given by

$k_{\mathrm{N} 2 \mathrm{O} 5}=\frac{1}{600 \exp \left(-\left(\frac{\mathrm{RH}}{28}\right)^{2.8}\right)+a}$

where $\mathrm{RH}$ is in units of $\%$ and the fitting variable $a=5$, which leads to a maximum $k_{\mathrm{N} 2 \mathrm{O} 5}$ of $0.003 \mathrm{~s}^{-1}$ at $\mathrm{RH}>60 \%$.

The third $\mathrm{N}_{2} \mathrm{O}_{5}$ uptake coefficient model (scheme D) is taken from Davis et al. (2008). In this approach, uptake coefficient for ammonium aerosols is modeled as a function of temperature, $\mathrm{RH}$, particle composition, and phase state. Briefly, this model uses regression fits of experimental uptake coefficients plotted as a function of $\mathrm{RH}$ and $T$. Coefficients (see $\beta$ values in Davis et al., Table 3.) are used to fit the experimental 10 data for $\left(\mathrm{NH}_{4}\right)_{2} \mathrm{SO}_{4}\left(\gamma_{1}\right), \mathrm{NH}_{4} \mathrm{HSO}_{4}\left(\gamma_{2}\right)$, and $\mathrm{NH}_{4} \mathrm{NO}_{3}\left(\gamma_{3}\right)$ (see Davis Eq. 1-3) that is transformed as the logit function $\ln (\gamma / 1-\gamma)$. These fits are then re transformed to derive the parameterized uptake coefficient using

$y_{i}=\frac{1}{1+e^{-\lambda_{i}}}$

Similar empirical equations were derived for uptake coefficients on dry particles, 15 mixed phase particles, and ice. For complete details the reader is referred to Davis et al. (2008).

In addition to the heterogeneous chemistry we added several modifications to the gas phase chemistry. We added two reactions that initiate DMS chemistry, one of which is a loss channel for nitrate radicals and generates $\mathrm{HNO}_{3}$, while the other is a 20 sink for $\mathrm{OH}$ radicals.

$$
\begin{aligned}
& \mathrm{NO}_{3}+\mathrm{DMS} \longrightarrow \mathrm{HNO}_{3}+\text { products } \\
& \mathrm{OH}+\mathrm{DMS} \longrightarrow \mathrm{H}_{2} \mathrm{O}+\text { products }
\end{aligned}
$$

These were added so that the importance of oceanic emissions in $\mathrm{NO}_{3}$ radical chemistry and $\Delta^{17} \mathrm{O}$ values might be investigated. Rate constants for all tropospheric reactions given by Stockwell et al. were checked and updated using the latest JPL guidelines for atmospheric chemistry (JPL, 2006). Changes in the latest rate constants for 5 HONO production were the only modifications.

After tracer, $\mathrm{N}_{2} \mathrm{O}_{5}$, and rate constant updates were coded into the model a series of calibration runs were carried out to evaluate its performance relative to previous studies. The evaluation consisted of using 18 test cases that are discussed by Stockwell et al. which vary a number of trace gas concentrations and use ozone production as 10 a validation metric. Our runs using the identical 18 test case scenarios produced the same $\mathrm{O}_{3}$ concentrations as given by Stockwell et al. (1997) within $2 \%$ indicating that no divergences arose from the additional coding.

\section{Model simulations}

\subsection{Sensitivity analysis}

15 A large combinatorial simulation was carried out by changing what we perceived are likely the most important variables for impacting $\Delta^{17} \mathrm{O}$ values. These are the starting pollutant concentrations, $\mathrm{CO}, \mathrm{CH}_{4}, \mathrm{O}_{3}, \mathrm{NO}_{\mathrm{x}}$, non methane hydrocarbon (NMHC), and biogenic volatile organic carbon (BVOC), water vapor mixing ratio, temperature, aerosol composition, aerosol loading (surface area), and season. For each variable we

20 selected low, medium and high values that represent the pristine, mean and extreme for various atmospheric environments, respectively. For example $\mathrm{NO}_{\mathrm{x}}$ flux high $=$ urban/plume, medium = rural, low = oceanic. Two seasons (winter $=1$ January, summer $=15$ June) were selected then the model was run for each combinatorial of the other 9 variables and their min, mean, and max values giving $\sim 3^{9}(\sim 20000)$ simulations. 


\section{Results and discussion}

A typical simulation of $\mathrm{NO}_{3}^{-}$atm $\Delta^{17} \mathrm{O}$ values over the course of a week is shown in Fig. 1. The model suggests that that there are (instantaneous) diurnal variations in the $\mathrm{NO}_{3}^{-}$atm $\Delta^{17} \mathrm{O}$ values. These are primarily produced by an increase in the $\alpha$ factor,

5 the proportion of $\mathrm{NO}$ oxidized by $\mathrm{O}_{3}$ during the night when peroxy radical production has been shut down, but also by a shift away from $\mathrm{NO}_{3}^{-}$atm produced via the $\beta(\mathrm{OH}$ oxidation) pathway during the day towards the $\varepsilon\left(\mathrm{N}_{2} \mathrm{O}_{5}\right)$ and $\chi\left(\mathrm{NO}_{3}\right)$ pathways at night (Fig. 2). The shift between $\beta$, $\chi$, and $\varepsilon$ pathways is highly influenced by trace gas concentrations as discussed below. The predicted diurnal variation, however, becomes washed out as the $\mathrm{NO}_{3}^{-}$atm builds up over several days and the bulk $\mathrm{NO}_{3}^{-}$atm $\Delta^{17} \mathrm{O}$ values (cumulative) converge on a value that reflects the mass weighted mean of the day and night $\mathrm{NO}_{3}^{-}$atm production. Since the atmospheric lifetime of $\mathrm{NO}_{3}^{-}$atm is on the order of a week, diurnal $\Delta^{17} \mathrm{O}$ variations in $\mathrm{NO}_{3}^{-}$atm are not likely to be observed. An exception to this may occur if $\mathrm{NO}_{3}^{-}$atm from urban areas is sampled diurnally directly 15 after intense precipitation events, when $\mathrm{NO}_{3}^{-}$atm has been rapidly removed by rain/wash out. In this case, since the $\mathrm{NO}_{3}^{-}$atm reservoir is nearly completely depleted, as $\mathrm{NO}_{x}$ emissions begin to rebuild $\mathrm{NO}_{3}^{-}$atm over the subsequent couple of days, the diurnal variation (2-5\%) could be detected using current analytical techniques.

ISO-RACM's prediction of $\mathrm{NO}_{3}^{-}$atm $\Delta^{17} \mathrm{O}$ values across all of the meteorology and

20 trace gas scenarios and evaluated using June photolysis parameters (20000 simulations) is shown in Fig. 3 along with the range of observed $\mathrm{NO}_{3}^{-}$atm $\Delta^{17} \mathrm{O}$ values (excluding polar region data). The model can not reproduce the observed data in $\sim 50 \%$ of the simulations when either the bulk $\mathrm{O}_{3} \Delta^{17} \mathrm{O}$ transfer mechanism or the terminal atom transfer mechanism is utilized. When the model is run using December photol-

25 ysis parameters (see below), however, only about $1 / 3$ of the simulations predict $\Delta^{17} \mathrm{O}$ values that are below the observed maximum of $32 \%$ when the terminal atom transfer mechanism is assumed while roughly $85 \%$ fall in the observational range using the bulk $\mathrm{O}_{3}$ mechanism. Given the limited number of $\mathrm{NO}_{3}^{-}$atm $\Delta^{17} \mathrm{O}$ observations (primarily

6843

from coastal/oceanic regions) that are available for evaluating the model, it remains unclear whether the terminal atom or bulk $\mathrm{O}_{3}$ is the valid mechanism. In either case, the ISO-RACM $\Delta^{17} \mathrm{O}$ simulations across these diverse set of conditions predict $\Delta^{17} \mathrm{O}$ values significantly below and above those currently observed in tropospheric mid lat5 itude aerosols. This highlights the need for additional isotopic analysis of precipitation and aerosol nitrate across a variety of environments that have diverse pollutant and meteorological conditions.

The importance of photolysis conditions for influencing $\mathrm{NO}_{3}^{-}$atm $\Delta^{17} \mathrm{O}$ values is shown in Fig. 4 ( 20000 runs). In this comparison of ISO-RACM runs all trace gas and me10 teorological conditions were identically varied, including temperature, but two different photolysis parameterizations were used (June and December). The data show that photolysis lifetime is clearly playing a role in $\mathrm{NO}_{3}^{-}$atm $\Delta{ }^{17} \mathrm{O}$ variability. The June photolysis simulations produces $\Delta^{17} \mathrm{O}$ values that are consistently a factor .83 lower than the December values $\left(r^{2}=.85\right)$. This effect is driven by two factors: first, the decrease

15 in daylight during the winter months leads to an increase in the $\alpha$ parameter meaning proportionately more $\mathrm{NO}$ is being oxidized by ozone (night chemistry). Second, the longer nights allow more conversion of $\mathrm{NO}_{x}$ to $\mathrm{NO}_{3}$ and $\mathrm{N}_{2} \mathrm{O}_{5}$ which increases the probability of the $\chi$ an $\varepsilon \mathrm{NO}_{3}^{-}$atm production channels become active. This photolysis effect in $\mathrm{NO}_{3}^{-}$atm $\Delta^{17} \mathrm{O}$ values has been observed over seasonal cycles at mid-latitude 20 sites (Michalski et al., 2003) but should also be observable, and amplified, along latitudinal transects (Morin et al., 2009) as a function of season. Cloud cover and aerosol scattering may also be a factor when attempting detailed modeling of $\mathrm{NO}_{3}^{-}$atm $^{17} \mathrm{O}$ variations. The effect of photolysis on $\mathrm{NO}_{3}^{-}{ }_{\text {atm }} \Delta^{17} \mathrm{O}$ values over the course of a year is to generate a sine wave, peaking in the winter and reaching a minimum in the summer,

25 similar to the observed annual variation (Michalski et al., 2003) and predictions by a recent global model (Alexander et al., 2009).

Figure 5 shows the differences between modeled $\Delta^{17} \mathrm{O}$ values when using $\mathrm{N}_{2} \mathrm{O}_{5}$ uptake schemes $\mathrm{C}$ or $\mathrm{D}$ relative to scheme $\mathrm{M}$ (using June photolysis). All three schemes predict approximately the same range of $\mathrm{NO}_{3}^{-}$atm $\Delta^{17} \mathrm{O}$ values (12-29\%) under condi6844 
tions detailed in Table 1. Most of the predicted $\mathrm{NO}_{3}^{-}$atm $\Delta^{17} \mathrm{O}$ values using either $\mathrm{N}_{2} \mathrm{O}_{5}$ schemes $\mathrm{D}$ or $\mathrm{C}$ are within $\pm 0.3 \%$ of the values predicted using scheme $\mathrm{M}$. There are, however, a considerable number of cases when the three schemes predict significantly different $\mathrm{NO}_{3}^{-}$atm $\Delta^{17} \mathrm{O}$ values. Scheme C's had a significant fraction of $\Delta^{17} \mathrm{O}$

5 predictions that are below (22\%), and a smaller fraction (16\%) above, the scheme $\mathrm{M}$ predicted values. The under/over prediction of $\Delta{ }^{17} \mathrm{O}$ values by Scheme $\mathrm{D}$ relative to scheme $\mathrm{M}$ are evenly split at $13 \%$. The magnitude of the over/under is typically on the order of $0.8 \%$ but can be as high as $\pm 2.4 \%$. This under/over prediction by $C$ and $D$ is due to the fact that these two schemes have a relative humidity (temperature) parameter, so that as relative humidity become high, the uptake coefficient becomes large leading to more $\mathrm{N}_{2} \mathrm{O}_{5}$ hydrolysis and higher $\Delta^{17} \mathrm{O}$ values. At low $\mathrm{RH}$, the opposite is true; $\mathrm{N}_{2} \mathrm{O}_{5}$ uptake coefficients are suppressed relative to the $\mathrm{M}$, which is independent of $\mathrm{RH}$, and $\Delta^{17} \mathrm{O}$ are depressed.

This is an important result because it suggests that under certain meteorological conditions or emission scenarios the different $\mathrm{N}_{2} \mathrm{O}_{5}$ hydrolysis parameterization schemes will predict different $\mathrm{NO}_{3}^{-}$atm $\Delta^{17} \mathrm{O}$ values. This means that $\Delta^{17} \mathrm{O}$ analysis of in situ $\mathrm{NO}_{3}^{-}$atm under a range of conditions may be a way of validating which $\mathrm{N}_{2} \mathrm{O}_{5}$ parameterizations are most effective in capturing the actual atmospheric chemistry. In particular conducting $\Delta^{17} \mathrm{O}$ analysis of nitrate collected in atmospheres with unique aerosol compositions (i.e. sulfate dominant, sulfate-nitrate, or organic-sulfate) and that have variable seasonal relative humidity's would be a way of validating uptake parameterization schemes. This highlights the fact that stable oxygen isotope analysis in nitrate (and sulfate) is a new way of validating chemical transport models and yields information (e.g. chemical pathway) not possible when using only concentration measurements as way of validating an atmospheric chemical model's predictive capability.

There is clearly a significant temperature dependence influencing $\mathrm{NO}_{3}^{-}{ }_{\mathrm{atm}} \Delta^{17} \mathrm{O}$ variations under different trace gas concentration scenarios (Fig. 6). The trend is towards higher $\Delta^{17} \mathrm{O}$ values, increasing by $1.5 \%$ o to $7 \%$, over the temperature rise from 275 to $305 \mathrm{~K}$. This temperature direction, increasing $\Delta^{17} \mathrm{O}$ with increasing $T$, is opposite of that 6845

one would expect based on the hypothesis (Michalski et al., 2003) that $\mathrm{N}_{2} \mathrm{O}_{5}$ stability in cold atmospheres is responsible for higher $\mathrm{NO}_{3}^{-}$atm $\Delta^{17} \mathrm{O}$ values in winter (i.e. low $T=$ high $\left.\Delta^{17} \mathrm{O}\right)$. Part of the temperature effect is due to the increase in $\mathrm{O}_{3} \Delta^{17} \mathrm{O}$ values via the temperature dependence of the $\Delta^{17} \mathrm{O}$ isotope effect in ozone, but this increase is 5 only $1.5 \%$ o(bulk) or $2.3 \%$ o (terminal) in the terminal) over this temperature range, which can only explain the lower bound in the $\mathrm{NO}_{3}^{-}{ }_{\text {atm }} \Delta^{17} \mathrm{O}$ increase. The additional increase in $\mathrm{NO}_{3}^{-}$atm $\Delta^{17} \mathrm{O}$ values is coming from the temperature dependence in rate constants that is shifting the relative importance of the $\alpha, \beta, \chi$, and $\varepsilon$ oxidation pathways. These oxidation parameters all exhibited some temperature induced variation, but the clear10 est and most consistent trend with temperature was found in $\beta$; the fraction of $\mathrm{HNO}_{3}$ produced by $\mathrm{OH}$ oxidation of $\mathrm{NO}_{2}$. High temperatures are suppressing the $\mathrm{OH}$ pathway so proportionately more $\mathrm{NO}_{3}^{-}$atm is produced by the $\chi$ and $\varepsilon$ pathways, which increases the $\Delta^{17} \mathrm{O}$ value. This temperature dependence may not be very important when comparing $\mathrm{NO}_{3}^{-}$atm $\Delta^{17} \mathrm{O}$ values in samples collected day to day at the same loca15 tion because such a large temperature swings are not likely to occur. The temperature effect on $\mathrm{NO}_{3}^{-}$atm $\Delta^{17} \mathrm{O}$ values would be more pronounced when comparing seasonal trends, but solar flux, as noted above, has a larger influence on the $\Delta^{17} \mathrm{O}$ value and may mask the temperature dependence. However, the effect is significant and should be considered when trying to model observed $\mathrm{NO}_{3}^{-}$atm $\Delta^{17} \mathrm{O}$ trends.

20 A large number of simulations were run to test which trace gas concentrations are important for controlling the chemistry that dictates $\mathrm{NO}_{3}^{-}{ }_{\text {atm }} \Delta^{17} \mathrm{O}$ values. These included another set of conditions that examined low, pre-anthropogenic type atmospheres as detailed in Table 1. In order to simplify the data interpretation we selected $\mathrm{N}_{2} \mathrm{O}_{5}$ scheme $\mathrm{M}$ as the test case and used June photolysis parameterization. Since wa-

25 ter mixing ratio (scheme $\mathrm{C}$ ) and percent bisulfate aerosol mass (scheme D) are not used in scheme M's uptake coefficient calculation, those variables were kept constant ( $1 \%$ and $0 \%$, respectively) as were temperature $(298 \mathrm{~K})$ and \% sulfate $(80 \%)$. 
There seems to be little impact on $\mathrm{NO}_{3 \text { atm }}^{-} \Delta^{17} \mathrm{O}$ values when $\mathrm{CO}$ and $\mathrm{CH}_{4}$ concentrations are varied to low, pre-anthropogenic values (Fig. 7), but changing VOC mixing ratios induces large effects (Fig. 8). When $\mathrm{CO}$ and $\mathrm{CH}_{4}$ are decreased to $25 \mathrm{ppbv}$ and $750 \mathrm{ppbv}$ respectively, the same range and pattern in $\Delta^{17} \mathrm{O}$ values were produced as

5 when present day mixing ratios (200 ppbv, $1700 \mathrm{ppbv}$ ) were used. This is because the relative rate of $\mathrm{NO}_{x}-\mathrm{O}_{3}$ catalytic cycling in much slower for the carbon monoxide and methane cycles relative to VOC or biogenic organic reactions. Conversely, when VOC concentrations increase, $\mathrm{NO}_{3}^{-}$atm $\Delta^{17} \mathrm{O}$ values tend to decrease. In fact the extremely low $\Delta^{17} \mathrm{O}$ values, (ones yet to be observed by in situ measurements), are under high 10 VOC mixing ratio scenarios. This VOC effect is due to a decrease in $\alpha$ with increasing VOC via enhanced oxidation on NO by organic peroxy radicals. A similar effect is observed with increases in biogenic VOCs for the same reasons. Such high VOC concentrations are only going to be found in highly VOC polluted urban regions (Houston e.g.) or in plumes (air craft, ships, stacks). This ISO-RACM prediction of decreas15 ing $\mathrm{NO}_{3 \mathrm{~atm}}^{-} \Delta^{17} \mathrm{O}$ values with increasing VOC could be tested by conducting isotope analysis of $\mathrm{NO}_{3}^{-}$atm collected at the surface, down wind of oil refinery or by sampling plumes.

Mixing ratios of $\mathrm{NO}_{x}$ and $\mathrm{O}_{3}$ are also predictors of the final range of $\mathrm{NO}_{3}^{-}{ }_{\text {atm }} \Delta^{17} \mathrm{O}$ values that might be generated. When $\mathrm{NO}_{x}$ mixing ratios are low (10-20 ppt) and 20 the system is in an ozone destruction regime, simulated $\mathrm{NO}_{3}^{-}{ }_{\mathrm{atm}} \Delta^{17} \mathrm{O}$ spans a wide range of values depending on other trace gases, primarily VOC/biogenic mixing ratios (Fig. 9). However, as $\mathrm{NO}_{x}$ mixing ratios increase to $100 \mathrm{pptv}$ the $\Delta^{17} \mathrm{O}$ values become more constrained and by $2 \mathrm{ppbv} \mathrm{NO}_{\mathrm{x}}$, only a narrow range of $\Delta^{17} \mathrm{O}$ values are observed regardless of $\mathrm{VOC} /$ biogenic mixing ratios. Similarly, high $\mathrm{O}_{3}$ mixing ratios $(20,50 \mathrm{ppbv})$

25 produce elevated $\Delta^{17} \mathrm{O}$ values (Fig. 10) that span a somewhat narrow range ( 5$10 \%$ ). But as $\mathrm{O}_{3}$ mixing ratios drop to $5 \mathrm{ppbv}$ or lower, the absolute values decrease and the range begins to expand $(\sim 15 \%)$ and at uncharacteristically low $\mathrm{O}_{3}$ mixing ratios $\left(<1-5\right.$ ppbv) $\mathrm{NO}_{3}^{-}$atm $\Delta^{17} \mathrm{O}$ values are typically less than $10 \%$ o but can approach zero.

6847

In these types of simulated atmospheres, very low $\mathrm{O}_{3} /$ high VOC/biogenic would not be typical of the troposphere and such low $\Delta^{17} \mathrm{O}$ values are not likely to be observed in $\mathrm{NO}_{3}^{-}$atm in the troposphere. Indeed, $\mathrm{O}_{3}$ mixing ratios at mid-latitudes rarely drop below $10 \mathrm{ppbv}$, therefore our model suggests that it is unlikely that $\mathrm{NO}_{3}^{-}$atm $\Delta^{17} \mathrm{O}$ values below $515 \%$ would be observed in the troposphere.

The range of $\mathrm{NO}_{3}^{-}$atm $\Delta^{17} \mathrm{O}$ values in predicted by ISO-RACM is similar to those predicted by other models, but there are some noteworthy differences. One difference worth mentioning is Alexander et al. (2009)'s predication of nitrate $\Delta^{17} \mathrm{O}$ values below 10 in the tropics (see Fig. 3 in Alexander et al., 2009). As discussed above, our model 10 does not predict $\Delta^{17} \mathrm{O}$ values below $15 \%$ under realistic conditions in the troposphere. These low estimates must be driven driven by peroxy radial oxidation, which may be higher in GEOS-Chem relative to ones predicted by ISO-RACM under high biogenic emission scenarios. Unfortunately there are no published seasonal measurements of aerosol or precipitation nitrate $\Delta^{17} \mathrm{O}$ values from these tropical regions for evaluat-

15 ing the two models predictive capability. ISO-RACM estimates that $\mathrm{NO}_{3}^{-}$atm produced by the $\mathrm{N}_{2} \mathrm{O}_{5}$ hydrolysis span 10 to $80 \%$ and is highly dependent on $\mathrm{NO}_{x}$ mixing ratios, aerosol surface area, and relative humidity. This is similar to our previous model results (Michalski et al., 2003), but significantly higher than the range estimated by Alexander et al. (2009) (5-50\%). This difference is likely due to high heterogeneous

$20 \quad \mathrm{~N}_{2} \mathrm{O}_{5}$ oxidation under urban and plume conditions that are not well represented in the global model. The $\mathrm{NO}_{3}^{-}$atm $\Delta^{17} \mathrm{O}$ values are sensitive to temperature, $\mathrm{NO}_{\mathrm{x}}, \mathrm{O}_{3}$, and VOC mixing ratios. These are a strong function of boundary layer height, particularly in urban regions. This suggests comparing multiple year/site in situ $\Delta^{17} \mathrm{O}$ data with $\Delta^{17} \mathrm{O}$ predications by single year 2-D and 3-D model analysis will also likely suffer biases 25 as a function of model grid size and annual local variations in these trace gas parameters. Point sources and chemical plumes in large scale grids will appear chemically dilute with respect to the chemistry creating $\mathrm{NO}_{3}^{-}$atm. Small, regional models such as CMAQ (grid size as small as $1 \mathrm{~km}^{2}$ ) would likely be more effective at capturing the actual chemical pathways and may be a better approach for modeling $\Delta^{17} \mathrm{O}$ in modern 
atmospheres.

\section{Conclusions and future work}

One of the objectives of this study is to use the model $\Delta^{17}$ O predictions as a basis for selecting field sites, archived samples (such as the National Atmospheric Deposition

5 Program or US-EPA $\mathrm{PM}_{2.5}$ archive), and collection techniques; $\mathrm{HNO}_{3}$ (g) vs. particulates. Based on these modeling results we expect to observe seasonal oscillations in $\mathrm{NO}_{3}^{-}$atm $\Delta^{17} \mathrm{O}$ values driven by changes in actinic flux that alters, primarily the $\alpha$ parameter. This oscillation would likely vanish near the tropics and become step like at higher latitudes mirroring seasonal actinic flux variations. Daily oscillations could be observed with high analytical precision $\left( \pm 0.3 \%\right.$ ) or when $\mathrm{NO}_{3}^{-}$atm is rapidly removed by rain after which $\mathrm{NO}_{x}$ emission would rebuild $\mathrm{NO}_{3}^{-}$atm over the subsequent days. In urban areas where $\mathrm{NO}_{x}$ and ozone are elevated the model suggests a narrow range of $\Delta^{17} \mathrm{O}$ values in $\mathrm{NO}_{3}^{-}$atm , with elevated absolute values. In rural-pristine areas, a slightly wider range and lower absolute value of $\Delta^{17} \mathrm{O}$ in $\mathrm{NO}_{3}^{-}$atm is expected, reaching 15 the lowest values under high organic loading and low $\mathrm{NO}_{\mathrm{x}} / \mathrm{O}_{3}$. This might be expected in the rural sites in the southern USA where isoprene emissions are significant due to emissions by deciduous trees but $\mathrm{NO}_{x}$ can remain low. If relative humidity is important in $\mathrm{N}_{2} \mathrm{O}_{5}$ hydrolysis, then we expect more significant $\Delta^{17} \mathrm{O}$ variations in regions with high and variable $\mathrm{RH}$ (Midwestern USA) relative to those with low, near constant $\mathrm{RH}$ 20 such as desert regions in the southwestern USA.

Simulating the dependence of $\mathrm{NO}_{3}^{-}$atm $\Delta^{17} \mathrm{O}$ values in different aerosol sizes would require a more sophisticated aerosol model, but some information can be gleaned from the present modeling results. Since $\mathrm{N}_{2} \mathrm{O}_{5}$ hydrolysis requires an aerosol surface for the reaction to occur, and that this pathway leads to higher $\Delta^{17} \mathrm{O}$ values in the re25 sulting $\mathrm{NO}_{3}^{-}$atm, at first blush one could conclude that the size fraction that dominates the aerosol surface area would have $\mathrm{NO}_{3(s)}^{-}$with the higher $\Delta^{17} \mathrm{O}$ values. This effect,

$$
6849
$$

however, would depend on the air mass and aerosol characteristics. The equilibrium between $\mathrm{HNO}_{3(\mathrm{~g})} \leftarrow \longrightarrow \mathrm{NH}_{4} \mathrm{NO}_{3(\mathrm{~s})}$ occurs on the order of minutes and is a strong function of temperature. Morino et al. (2009) showed there were strong diurnal, seasonal, and altitudinal shifts in equilibrium due to the temperature (and $\mathrm{RH}$ ) dependency of the 5 equilibrium. For example, during daytime in the summer nearly $90 \%$ of $\mathrm{NO}_{3}^{-}$atm can be gaseous $\mathrm{HNO}_{3}$. Therefore even though $\mathrm{NO}_{3}^{-}$atm may be formed on aerosol surfaces at night via Reactions (R6) it would transition to the gas phase during the day. Chemical equilibrium will also be dependent on aerosol composition. The large shift in the gasparticle equilibrium usually assumes $\mathrm{NH}_{4}^{+}$is the dominant cation, which is not always

10 the case. In coastal or open ocean air masses $\mathrm{NaCl}$ can be the dominant contributor to the surface area. In this case, due to chloride displacement as $\mathrm{HCl}, \mathrm{N}_{2} \mathrm{O}_{5}$ hydrolysis would lead to $\mathrm{NaNO}_{3}(\mathrm{~s})$ formation, not $\mathrm{H}^{+}+\mathrm{NO}_{3}^{-}$. Here the equilibrium towards the gas phase is very weak, and nitrate would remain bound on sea salt particles, therefore one might expect high $\Delta^{17} \mathrm{O}$ values in the sea salt size fraction (>2.5 micron) (Patris et

15 al., 2007; Morin et al., 2009) relative to smaller aerosols that might have higher surface area, but are also often acidic. By the same arguments, however, uptake of $\mathrm{HNO}_{3(\mathrm{~g})}$ onto sea salt particles would also be thermodynamically favorable, therefore loss of $\mathrm{HNO}_{3(\mathrm{~g})}$ formed by $\mathrm{NO}_{2}+\mathrm{OH}$ (with low $\Delta^{17} \mathrm{O}$ signatures) would readily mix with $\mathrm{N}_{2} \mathrm{O}_{5}$ reactions on the same particles. One situation where it may be possible to use $\Delta^{17} \mathrm{O}$ 20 measurements to see the Reactions (R3) and (R6) in different aerosol sizes is in mid latitude agricultural regions in the Midwest during winter. In these regions there is often high $\mathrm{NH}_{3}$ emissions that would facilitate the $\mathrm{HNO}_{3(\mathrm{~g})}+\mathrm{NH}_{3} \longrightarrow \mathrm{NH}_{4} \mathrm{NO}_{3}$ and the cold temperatures would retain it in the aerosol phase. Because this is a gas to particle reaction, this would be seen in the Aiken size fraction or accumulation mode. However, aerosol surface area is still dominated by sub micron dust, sulfate, and biogenic aerosols arising from agriculture and coal combustion in the region. These particles would facilitate the $\mathrm{N}_{2} \mathrm{O}_{5}$ hydrolysis reaction and lead to high $\Delta^{17} \mathrm{O}$ values in $\mathrm{NO}_{3(\mathrm{~s})}^{-}$. Much would depend on the chemical characteristics of the different aerosol size distributions and modeling this would require an explicit aerosol dynamics module that 
incorporates the isotope mass balance model.

The results presented here suggests that $\Delta^{17} \mathrm{O}$ analysis in $\mathrm{NO}_{3}^{-}$atm is potentially an important new tool for understanding in situ $\mathrm{NO}_{x}-\mathrm{NO}_{y}$ chemistry and aerosol production mechanisms, but additional studies need to be conducted to effectively utilize this 5 stable isotope tool. Foremost, is the need for additional measurements of $\Delta^{17} \mathrm{O}$ in a diverse set of locations where $\mathrm{NO}_{3}^{-}$atm formation pathways are expected to vary and interact with different oxidation intermediates. Oceanic, tropical, desert, forested and rural areas are not well represented in the current data sets, which itself is incredibly limited. One of the key shortcomings of the model is the uncertainty in the $\mathrm{O}_{3}-\mathrm{NO}$ transfer mechanism and how that relates to tropospheric $\mathrm{O}_{3} \Delta^{17} \mathrm{O}$ values. An experimental determination of $\Delta^{17} \mathrm{O}$ generated in $\mathrm{NO}_{\mathrm{x}}$ through the Leighton reactions would be a significant advance. Experimental evidence for any isotope effect associated with the $\mathrm{NO}+\mathrm{HO}_{2}$ reaction would also limit much of the uncertainty in the current assumptions in the mass balance model. Clearly there is room for improvement in the modeling

15 aspects. Given the short lifetime of $\mathrm{NO}_{3}^{-}$atm and the importance of point sources and plume chemistry, large grid scale global models may not be as effective in predicting $\mathrm{NO}_{3 \text { atm }}^{-} \Delta^{17} \mathrm{O}$ when influenced by human emissions as more detailed, regional models such a CMAQ or WRF-Chem. Finally, more effort is needed to incorporate the other isotopic tracers in $\mathrm{NO}_{3}^{-}{ }_{\text {atm }}, \delta^{15} \mathrm{~N}$ and $\delta^{18} \mathrm{O}$, into model simulations. This adds com20 plexity because it requires not only understanding the kinetic and equilibrium isotope effects that occur during $\mathrm{NO}_{\mathrm{x}}-\mathrm{NO}_{y}$ cycling, but also $\delta^{15} \mathrm{~N}$ variations arising from $\mathrm{NO}_{\mathrm{x}}$ sources and $\delta^{18} \mathrm{O}$ variations arising from water vapor, which has distinct $\delta^{18} \mathrm{O}$ values as a function of time and space.

Acknowledgements. We gratefully acknowledge the National Science Foundations for support 25 through grant AGS-0856274 and Purdue University/NSF through the Summer Undergraduate Research Fellowship (SURF) program. Thanks to Larry Michalski for his assistance with the linux system. William Stockwell generously provided us with the RACM source code.

\section{References}

Alexander, B., Hastings, M. G., Allman, D. J., Dachs, J., Thornton, J. A., and Kunasek, S. A.: Quantifying atmospheric nitrate formation pathways based on a global model of the oxygen isotopic composition $\left(\Delta^{17} \mathrm{O}\right)$ of atmospheric nitrate, Atmos. Chem. Phys., 9, 5043-5056,

$5 \quad 2009$, http://www.atmos-chem-phys.net/9/5043/2009/.

Alexander, B., Park, R. J., Jacob, D. J., Li, Q. B., Yantosca, R. M., Savarino, J., Lee, C. C. W., and Thiemens, M. H.: Sulfate formation in sea-salt aerosols: Constraints from oxygen isotopes, J. Geophys. Res., 110(D10), D10307, doi:10.1029/2004JD005659, 2005.

Atkinson, R.: Atmospheric chemistry of VOCs and $\mathrm{NO}_{\mathrm{x}}, 2063-2101,2000$.

10 Bauer, S. E., Koch, D., Unger, N., Metzger, S. M., Shindell, D. T., and Streets, D. G.: Nitrate aerosols today and in 2030: a global simulation including aerosols and tropospheric ozone, Atmos. Chem. Phys., 7, 5043-5059, 2007, http://www.atmos-chem-phys.net/7/5043/2007/.

Bedison, J. E. and Mcneil, B. E.: Is the growth of temperate forest trees enhanced along an ambient nitrogen deposition gradient?, Ecology, 90(7), 1736-1742, 2009.

Bhattacharya, S. K. and Thiemens, M. H.: New evidence for symmetry dependent isotope effects: atomic oxygen + carbon monoxide reaction, Z. Naturforsch. A., 44(5), 435-444, 1989.

Bhattacharya, S. K., Savarino, J., and Thiemens, M. H.: A new class of oxygen isotopic frac-

20 tionation in photodissociation of carbon dioxide: potential implications for atmospheres of Mars and Earth, Geophys. Res. Lett., 27(10), 1459-1462, 2000.

Bhattacharya, S. K., Pandey, A. and Savarino, J.: Determination of intramolecular isotope distribution of ozone by oxidation reaction with silver metal, J. Geophys. Res., 113, D03303, doi:10.1029/2006JD008309, 2008.

25 Brown, S. S., Ryerson, T. B., Wollny, A. G., Brock, C. A., Peltier, R., Sullivan, A. P., Weber, R. J., Dube, W. P., Trainer, M., Meagher, J. F., Fehsenfeld, F. C., and Ravishankara, A. R.: Variability in nocturnal nitrogen oxide processing and its role in regional air quality, Science, 311(5757), 67-70, 2006.

Brown, S. S., Stark, H., Ryerson, T. B., Williams, E. J., Nicks, D. K., Trainer, M., Fehsenfeld, F. C., and Ravishankara, A. R.: Nitrogen oxides in the nocturnal boundary layer: Simultaneous in situ measurements of $\mathrm{NO}_{3}, \mathrm{~N}_{2} \mathrm{O}_{5}, \mathrm{NO}_{2}, \mathrm{NO}$, and $\mathrm{O}_{3}$, J. Geophys. Res., 108(D9), 4299, doi:10.1029/2002JD002917, 2003. 
Chang, J. S., Brost, R. A., Isaksen, I. S. A., Madronich, S., Middleton, P., Stockwell, W. R., and Walcek, C. J.: A 3-Dimensional Eulerian Acid Deposition Model - Physical Concepts and Formulation, J. Geophys. Res., 92(D12), 14681-14700, 1987.

Davis, J. M., Bhave, P. V., and Foley, K. M.: Parameterization of N2O5 reaction probabilities on

5 the surface of particles containing ammonium, sulfate, and nitrate, Atm. Chem. Phys., 8(17), 5295-5311, 2008

Delmas, R. J.: Ice-core records of global climate and environment changes, P. Indian AS-Earth, 107(4), 307-319, 1998.

Dentener, F., Drevet, J., Lamarque, J. F., Bey, I., Eickhout, B., Fiore, A. M., Hauglustaine, D., Horowitz, L. W., Krol, M., Kulshrestha, U. C., Lawrence, M., Galy-Lacaux, C., Rast, S., Shindell, D., Stevenson, D., Van Noije, T., Atherton, C., Bell, N., Bergman, D., Butler, T., Cofala, J., Collins, B., Doherty, R., Ellingsen, K., Galloway, J., Gauss, M., Montanaro, V., Muller, J. F., Pitari, G., Rodriguez, J., Sanderson, M., Solmon, F., Strahan, S., Schultz, M., Sudo, K., Szopa, S., and Wild, O.: Nitrogen and sulfur deposition on regional and global scales: A mul-

15 timodel evaluation, Global Biogeochem. Cy., 20(4), GB4003 doi:10.1029/2005GB002672, 2006.

Dubey, M. K., Mohrschladt, R., Donahue, N. M., and Anderson, J. G.: Isotope-specific kinetics of hydroxyl radical $(\mathrm{OH})$ with water $\left(\mathrm{H}_{2} \mathrm{O}\right)$ : Testing models of reactivity and atmospheric fractionation, J. Phys. Chem. A, 101(8), 1494-1500, 1997.

20 Fenn, M. E., Haeuber, R., Tonnesen, G. S., Baron, J. S., Grossman-Clarke, S., Hope, D., Jaffe, D. A., Copeland, S., Geiser, L., Rueth, H. M., and Sickman, J. O.: Nitrogen emissions, deposition, and monitoring in the western United States, 391-403, 2003.

Finlayson-Pitts, B. J. and Pitts Jr., J. N.: Chemistry of the Upper and Lower Atmosphere, Academic Press, San Diego, 2000.

25 Friedl, R. R., Golden, D. M., Kurylo, M. J., Moortgat, G. K., Keller-Rudek, H., Wine, P. H., Ravishankara, A. R., Kolb, C. E., Molina, M. J., Finlayson-Pitts, B. J., Huie, R. E., and Orkin, V. L.: Chemical Kinetics and Photochemical Data for Use in Atmospheric Studies Evaluation Number 15, Jet Propulsion Laboratory, JPL Publication 06-2, 2006.

Freyer, H. D.: Seasonal-Variation of N-15-N-14 Ratios in Atmospheric Nitrate Species, Tellus B, 43(1), 30-44, 1991.

Galloway, J. N.: Acid deposition: perspectives in time and space, Water Air Soil Poll., 85(1), 15-24, 1995.

Galloway, J. N., Dentener, F. J., Capone, D. G., Boyer, E. W., Howarth, R. W., Seitzinger, S.

6853

P., Asner, G. P., Cleveland, C. C., Green, P. A., Holland, E. A., Karl, D. M., Michaels, A. F., Porter, J. H., Townsend, A. R., and Vorosmarty, C. J.: Nitrogen cycles: past, present, and future, Biogeochemistry, 70(2), 153-226, 2004.

Gladysheva, O. G., Dmitriev, P. B., Barkov, N. I., Ekaikin, A. A., and Nikonorov, V. V.: Nitrate content of snow at Vostok station, Antarctica, Geomagn. Aeronomy, 43(5), 665-669, 2003.

Gross, A. and Stockwell, W. R.: Comparison of the EMEP, RADM2 and RACM mechanisms, J. Atmos. Chem., 44(2), 151-170, 2003.

Gross, A., Sorensen, J. H., and Stockwell, W. R.: A multi-trajectory chemical-transport vectorized gear model: 3-D simulations and model validation, J. Atmos. Chem., 50(3), 211-242, 2005.

Hallquist, M., Stewart, D. J., Baker, J., and Cox, R. A.: Hydrolysis of $\mathrm{N}_{2} \mathrm{O}_{5}$ on submicron sulfuric acid aerosols, J. Phys. Chem. A, 10(17), 3984-3990, 2000.

Hansen, J., Sato, M., Ruedy, R., Nazarenko, L., Lacis, A., Schmidt, G. A., Russell, G., Aleinov, I., Bauer, M., Bauer, S., Bell, N., Cairns, B., Canuto, V., Chandler, M., Cheng, Y., Del Genio,

15 A., Faluvegi, G., Fleming, E., Friend, A., Hall, T., Jackman, C., Kelley, M., Kiang, N., Koch, D., Lean, J., Lerner, J., Lo, K., Menon, S., Miller, R., Minnis, P., Novakov, T., Oinas, V., Perlwitz, J., Perlwitz, J., Rind, D., Romanou, A., Shindell, D., Stone, P., Sun, S., Tausnev, N., Thresher, D., Wielicki, B., Wong, T., Yao, M., and Zhang, S.: Efficacy of climate forcings, J. Geophys. Res., 110(D18), D18104, doi:10.1029/2005JD005776, 2005.

20 Hastings, M. G., D. M. Sigman and E. J. Steig, Seasonal variations in N and O isotopes of nitrate in snow at Summit, Greenland: Implications for the study of nitrate in snow and ice cores, J. Geophys. Res., 109, D20306, doi:10.1029/2004JD004991, 2004.

Haywood, J. and Boucher, O.: Estimates of the direct and indirect radiative forcing due to tropospheric aerosols: A review, Rev. Geophys., 38(4), 513-543, 2000.

25 Horowitz, L. W., Fiore, A. M., Milly, G. P., Cohen, R. C., Perring, A., Wooldridge, P. J., Hess, P. G., Emmons, L. K., and Lamarque, J. F.: Observational constraints on the chemistry of isoprene nitrates over the eastern United States, J. Geophys. Res., 112(D12), D12S08, doi:10.1029/2006JD007747, 2007.

Johnston, J. C. and Thiemens, M. H.: The isotopic composition of tropospheric ozone in three environments, J. Geophys. Res., 102(D21), 25395-25404, 1997.

Kirchner, F. and Stockwell, W. R.: Effect of peroxy radical reactions on the predicted concentrations of ozone, nitrogenous compounds, and radicals , J. Geophys. Res., 101, 21007, 1996. 
Krankowsky, D., Bartecki, F., Klees, G. G., Mauersberger, K., Schellenbach, K., and Stehr, $\mathrm{J}$.: Measurement of heavy isotope enrichment in tropospheric ozone, Geophys. Res. Lett., 22(13), 1713-1716, 1995.

Kuhn, M., Builtjes, P. J. H., Poppe, D., Simpson, D., Stockwell, W. R., Andersson-Skold, Y., 5 Baart, A., Das, M., Fiedler, F., Hov, O., Kirchner, F., Makar, P. A., Milford, J. B., Roemer, M. G. M., Ruhnke, R., Strand, A., Vogel, B., and Vogel, H.: Intercomparison of the gasphase chemistry in several chemistry and transport models, Atmos. Environ., 32(4), 693709, 1998.

Li, S., Wang, T. J., Zhuang, B. L., and Han, Y.: Indirect radiative forcing and climatic effect of the anthropogenic nitrate aerosol on regional climate of China, Adv. Atmos. Sci., 26(3), 543-552, 2009.

Lohmann, U. and Lesins, G.: Stronger constraints on the anthropogenic indirect aerosol effect, Science, 298(5595), 1012-1015, 2002.

Luz, B., Barkan, E., Bender, M. L., Thiemens, M. H., and Boering, K. A.: Triple-isotope com-

15 position of atmospheric oxygen as a tracer of biosphere productivity, Nature, 400(6744), 547-550, 1999.

Lyons, J. R.: Transfer of mass-independent fractionation in ozone to other oxygen-containing radicals in the atmosphere, Geophys. Res. Lett., 28(17), 3231-3234, 2001.

Magill, A. H., Aber, J. D., Currie, W. S., Nadelhoffer, K. J., Martin, M. E., McDowell, W. H., Melillo, J. M., and Steudler, P.: Ecosystem response to 15 years of chronic nitrogen additions at the Harvard Forest LTER, Massachusetts, USA, Forest Ecol. Manag., 196(1), 7-28, 2004.

Mentel, T. F., Sohn, M., and Wahner, A.: Nitrate effect in the heterogeneous hydrolysis of dinitrogen pentoxide on aqueous aerosols, Phys. Chem. Chem. Phys., 1(24), 5451-5457, 1999.

25 Michalski, G., Scott, Z., Kabiling, M., and Thiemens, M.: First Measurements and Modeling of $\Delta^{17} \mathrm{O}$ in Atmospheric Nitrate, Geophys. Res. Lett., 30(16), 1870, doi:10.1029GL017015, 2003.

Michalski, G. and Bhattacharya, S. K.: The role of symmetry in the mass independent isotope effect in ozone, Proc. Nat. Acad. Sci., 106, 5493-5496, 2009.

30 Michalski, G., Böhlke, J. K., and Thiemens, M. H.: Long Term Atmospheric Deposition as the Source of Nitrate and Other Salts in the Atacama Desert, Chile: New Evidence from MassIndependent Oxygen Isotopic Compositions, Geochim. Cosmochim. Ac., 68, 4023-4038, 2004.

\section{5}

Miller, M. F.: Isotopic fractionation and the quantification of ${ }^{17} \mathrm{O}$ anomalies in the oxygen threeisotope system: an appraisal and geochemical significance, Geochim. Cosmochim. Ac., 66(11), 1881-1889, 2002.

Morin, S., Savarino, J., Frey, M. M., Domine, F., Jacobi, H. W., Kaleschke, L., and Martins, J. M. F.: Comprehensive isotopic composition of atmospheric nitrate in the Atlantic Ocean boundary layer from 65 degrees S to 79 degrees N, J. Geophys. Res., 114, D05303, doi:10.1029/2008JD010696, 2009.

Morin, S., Savarino, J., Bekki, S., Gong, S., and Bottenheim, J. W.: Signature of Arctic surface ozone depletion events in the isotope anomaly $\left(\Delta^{17} \mathrm{O}\right)$ of atmospheric nitrate, Atmos. Chem. Phys., 7, 1451-1469, 2007, http://www.atmos-chem-phys.net/7/1451/2007/.

Morton, J., Barnes, J., Schueler, B., and Mauersberger, K.: Laboratory Studies of Heavy Ozone, J. Geophys. Res., 95(D1), 901-907, 1990.

Mozurkewich, M. and Calvert, J. G.: Reaction Probability of $\mathrm{N}_{2} \mathrm{O}_{5}$ on Aqueous Aerosols, J. Geophys. Res., 93(D12), 15889-15896, 1988.

15 Myhre, G.: Consistency Between Satellite-Derived and Modeled Estimates of the Direct Aerosol Effect, Science, 325(5937), 187-190, 2009.

Paerl, H. W., Boynton, W. R., Dennis, R. L., Driscoll, C. T., Greening, H. S., Kremer, J. N., Rabalais, N., and Seitzinger, S. P.: Atmospheric deposition of nitrogen in coastal waters: Biogeochemical and ecological implications, in: Nitrogen loading in coastal water bodies: an atmospheric perspective, edited by: Valigura, R. A., Alexander, R. B., Castro, M. S., Meyers, T., Paerl, H. W., Stacey, P. E., and Turner, R. E., American Geophysical Union, Washington, 11-52, 2001.

Patris, N., Cliff, S. S., Quinn, P. K., Kasem, M., and Thiemens, M. H.: Isotopic analysis of aerosol sulfate and nitrate during ITCT-2k2: Determination of different formation pathways as a function of particle size, J. Geophys. Res., 112(D23), D23301, doi:10.1029/2005JD006214, 2007.

Peiro-Garcia, J. and Nebot-Gil, I.: Ab initio study of the mechanism of the atmospheric reaction: $\mathrm{NO}_{2}+\mathrm{O}_{3}->\mathrm{NO}_{3}+\mathrm{O}_{2}$, J. Comput. Chem., 24(13), 1657-1663, 2003.

Peiro-Garcia, J. and Nebot-Gil, I.: Ab initio study of the mechanism and thermochemistry of the atmospheric reaction $\mathrm{NO}+\mathrm{O}_{3}->\mathrm{NO}_{2}+\mathrm{O}_{2}$, J. Phys. Chem. A, 106(43), 10302-10310, 2002.

Perring, A. E., Wisthaler, A., Graus, M., Wooldridge, P. J., Lockwood, A. L., Mielke, L. H., Shepson, P. B., Hansel, A., and Cohen, R. C.: A product study of the isoprene $+\mathrm{NO}_{3}$ reaction, Atmos. Chem. Phys., 9, 4945-4956, 2009, 
http://www.atmos-chem-phys.net/9/4945/2009/.

Platt, U. F., Winer, A. M., Biermann, H. W., Atkinson, R., and Pitts, J. N.: Measurement of Nitrate Radical Concentrations in Continental Air, Environ. Sci. Technol., 18(5), 365-369, 1984.

5 Redpath, A. E., Menzinger, M., and Carrington, T.: Molecular-Beam Chemiluminescence: Kinetic and internal energy dependence of $\mathrm{NO}+\mathrm{O}_{3}->\mathrm{NO}_{2}{ }^{*} \rightarrow \mathrm{NO}_{2}+\mathrm{hn}$ reaction, Chem. Phys., 27(3), 409-431, 1978.

Riemer, N., Vogel, H., Vogel, B., Schell, B., Ackermann, I., Kessler, C., and Hass, H.: Impact of the heterogeneous hydrolysis of $\mathrm{N}_{2} \mathrm{O}_{5}$ on chemistry and nitrate aerosol formation in the lower troposphere under photosmog conditions, J. Geophys. Res., 108(D4), 4144, doi:10.1029/2002JD002436, 2003.

Rockmann, T., Brenninkmeijer, C. A. M., Sauerssig, G., Bergamaschi, P., Crowley, J. N., Fischer, H., and Crutzen, P. J.: Mass-independent oxygen isotope fractionation in atmospheric $\mathrm{CO}$ as a result of the reaction $\mathrm{CO}+\mathrm{OH}$, Science, 281(5376), 544-546, 1998.

15 Rodhe, H., Dentener, F., and Schulz, M.: The global distribution of acidifying wet deposition, Environ. Sci. Technol., 36(20), 4382-4388, 2002.

Samet, J. M., Dominici, F., Curriero, F. C., Coursac, I., and Zeger, S. L.: Fine particulate air pollution and mortality in 20 US cities, 1987-1994, pp. 1742-1749, 2000.

Savarino, J. and Thiemens, M. H.: Mass-independent oxygen isotope $\left({ }^{16} \mathrm{O},{ }^{17} \mathrm{O},{ }^{18} \mathrm{O}\right)$ fractionation found in $\mathrm{H}_{\mathrm{x}}, \mathrm{O}_{\mathrm{x}}$ reactions, J. Phys. Chem. A, 103(46), 9221-9229, 1999.

Savarino, J. and Thiemens, M. H.: Analytical procedure to determine both $\delta^{18} \mathrm{O}$ and $\delta^{17} \mathrm{O}$ of $\mathrm{H}_{2} \mathrm{O}_{2}$ in natural water and first measurements, Atmos. Environ., 33(22), 3683-3690, 1999.

Savarino, J., Bhattacharya, S. K., Morin, S., Baroni, M., and Doussin, J. F.: The $\mathrm{NO}+\mathrm{O}_{3}$ reaction: A triple oxygen isotope perspective on the reaction dynamics and atmospheric im-

25 plications for the transfer of the ozone isotope anomaly, J. Chem. Phys., 128(19), 194303, doi:10.1063/1.2917581, 2008.

Schwartz, J. and Neas, L. M.: Fine particles are more strongly associated than coarse particles with acute respiratory health effects in schoolchildren, Epidemiology, 11(1), 6-10, 2000.

Scheuner, E. T. and Makeschin, F.: Impact of atmospheric nitrogen deposition on carbon dynamics in two scots pine forest soils of northern germany, Plant Soil, 275(1-2), 43-54, 2005.

Seinfeld, J. H. and Pandis, S. N.: Atmospheric chemistry and physics: from air pollution to climate change, New York, Wiley, 1998.

Sinha, A., Lovejoy, E. R., and Howard, C. J.: Kinetic-Study of the Reaction of $\mathrm{HO}_{2}$ with Ozone, 6857

J. Chem. Phys., 87(4), 2122-2128, 1987.

Stark, H., Brown, S. S., Goldan, P. D., Aldener, M., Kuster, W. C., Jakoubek, R., Fehsenfeld, F. C., Meagher, J., Bates, T. S., and Ravishankara, A. R.: Influence of nitrate radical on the oxidation of dimethyl sulfide in a polluted marine environment, J. Geophys. Res., 112(D10), D10S10, doi:10.1029/2006JD007669, 2007.

Stockwell, W. R., Kirchner, F., Kuhn, M., and Seefeld, S.: A new mechanism for regional atmospheric chemistry modeling, J. Geophys. Res., 102(D22), 25847-25879, 1997.

Thiemens, M. H. and Heidenreich III, J. E.: The mass-independent fractionation of oxygen: a novel isotope effect and its possible cosmochemical implications, Science, 219(4588), 10731075, 1983.

Thiemens, M. H. and Jackson, T.: Pressure dependency for heavy isotope enhancement in ozone formation, Geophys. Res. Lett., 17(6), 717-719, 1990.

Thiemens, M. H. and Jackson, T.: Production of isotopically heavy ozone by ultraviolet light photolysis of oxygen, Geophys. Res. Lett., 14(6), 624-627, 1987.

15 Tuazon, E. C., Atkinson, R., Plum, C. N., Winer, A. M., and Pitts, J. N.: The Reaction of GasPhase $\mathrm{N}_{2} \mathrm{O}_{5}$ with Water-Vapor, Geophys. Res. Lett., 10(10), 953-956, 1983.

Urey, H. C.: Thermodynamic properties of isotopic substances, J. Chem. Soc., 562-581, 1947.

Viswanathan, R. and Raff, L. M.: Theoretical investigations of the reaction dynamics of polyatomic gas-phase systems: the ozone + nitric oxide reaction, J. Phys. Chem., 87(17), 32513266, 1983.

Wahner, A., Mentel, T. F., and Sohn, M.: Gas-phase reaction of $\mathrm{N}_{2} \mathrm{O}_{5}$ with water vapor: Importance of heterogeneous hydrolysis of $\mathrm{N}_{2} \mathrm{O}_{5}$ and surface desorption of $\mathrm{HNO}_{3}$ in a large teflon chamber, Geophys. Res. Lett., 25(12), 2169-2172, 1998.

Wahner, A., Mentel, T. F., Sohn, M., and Stier, J.: Heterogeneous reaction of $\mathrm{N}_{2} \mathrm{O}_{5}$ on sodium nitrate aerosol, J. Geophys. Res., 103(D23), 31103-31112, 1998.

Yvon, S. A., Plane, J. M. C., Nien, C.-F., Cooper, D. J. and Saltzman, E. S.: Interaction between nitrogen and sulfur cycles in the polluted marine boundary layer, J. Geophys. Res., 101(D1), 1379-1386, 1996. 
Table 1. ISO-RACM simulations initial conditions.

\begin{tabular}{|c|c|c|c|}
\hline Flux & High & Med & Low \\
\hline $\mathrm{NO}_{x} / \mathrm{CO}$ flux $\left(\mu \mathrm{mol} / \mathrm{m}^{2} /\right.$ day $)$ & 6 & 0.6 & .006 \\
\hline NMHC flux $\left(\mu \mathrm{mol} C / \mathrm{m}^{2} /\right.$ day $)$ & 1000 & 100 & 1 \\
\hline BVOC flux $\left(\mu \mathrm{mol} / \mathrm{m}^{2} /\right.$ day $)$ & 2000 & 100 & 1 \\
\hline \multicolumn{4}{|l|}{ Initial conditions } \\
\hline$\left[\mathrm{H}_{2} \mathrm{O}\right]$ & $3 \%$ & $1 \%$ & $0.5 \%$ \\
\hline Temp. (K) & 310 & 298 & 270 \\
\hline Aerosol mass $\left(\mu \mathrm{g} / \mathrm{m}^{3}\right)$ & 100 & 10 & 1 \\
\hline$\%$ aerosol $\mathrm{SO}_{4}^{2-}$ & 95 & 60 & 10 \\
\hline$\% \mathrm{NH}_{4} \mathrm{HSO}_{4}$ & 100 & 50 & 10 \\
\hline $\mathrm{N}_{2} \mathrm{O}_{5}$ scheme & 1 & 2 & 3 \\
\hline $\mathrm{NO}_{\mathrm{x}}(\mathrm{ppbv})$ & 1 & 10 & 30 \\
\hline $\mathrm{O}_{3}$ (ppbv) & 10 & 50 & 80 \\
\hline CO (ppbv) & 100 & 200 & 300 \\
\hline $\mathrm{CH}_{4}$ (ppbv) & 1600 & 1750 & 1800 \\
\hline VOC (ppbv as C) & 10 & 100 & 1000 \\
\hline BVOC (ppbv as C) & 1 & 10 & 200 \\
\hline \multicolumn{4}{|l|}{ Pre-anthroprogenic } \\
\hline $\mathrm{NO}_{\mathrm{x}}(\mathrm{pptv})$ & 10,20 & 100 & 2000 \\
\hline $\mathrm{O}_{3}$ (ppbv) & 1,10 & 20 & 50 \\
\hline $\mathrm{CO}$ (ppbv) & 25,50 & 100 & 200 \\
\hline $\mathrm{CH}_{4}(\mathrm{ppbv})$ & 750,900 & 1100 & 1700 \\
\hline VOC (ppbv as C) & 1 & 10 & 100 \\
\hline BVOC (ppbv as C) & 1 & 10 & 200 \\
\hline
\end{tabular}

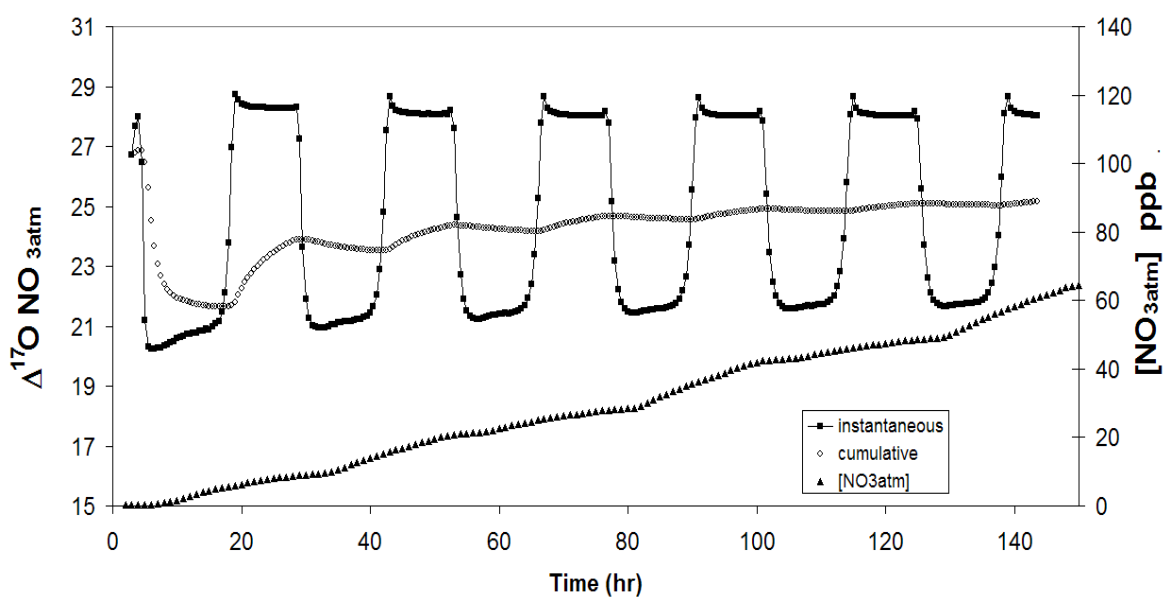

Fig. 1. Simulated instantaneous and cumulative change in $\mathrm{NO}_{3}^{-}$atm $\Delta^{17} \mathrm{O}$ values (in \%o) using test case 1 (time $(0)=0600$ ). The minima in the simulated instantaneous $\Delta^{17} \mathrm{O}$ values of $\sim 21 \%$ o correspond to $\mathrm{NO}_{3}^{-}$atm production dominated by the reaction $\mathrm{OH}+\mathrm{NO}_{2}$ during the daytime. Instantaneous maximums at night are primarily due to increases in $\mathrm{NO}$ oxidation by $\mathrm{O}_{3}$ at night and by $\mathrm{NO}_{3}^{-}$atm production via $\mathrm{N}_{2} \mathrm{O}_{5}$ hydrolysis. Diurnal variation in the modeled cumulative $\Delta^{17} \mathrm{O}$ signal are washed out by day 3 as $\mathrm{NO}_{3}^{-}$atm accumulates in the atmosphere resulting in a mean $\Delta^{17}$ O values of $\sim 25 \%$ o under test case 1 conditions. 


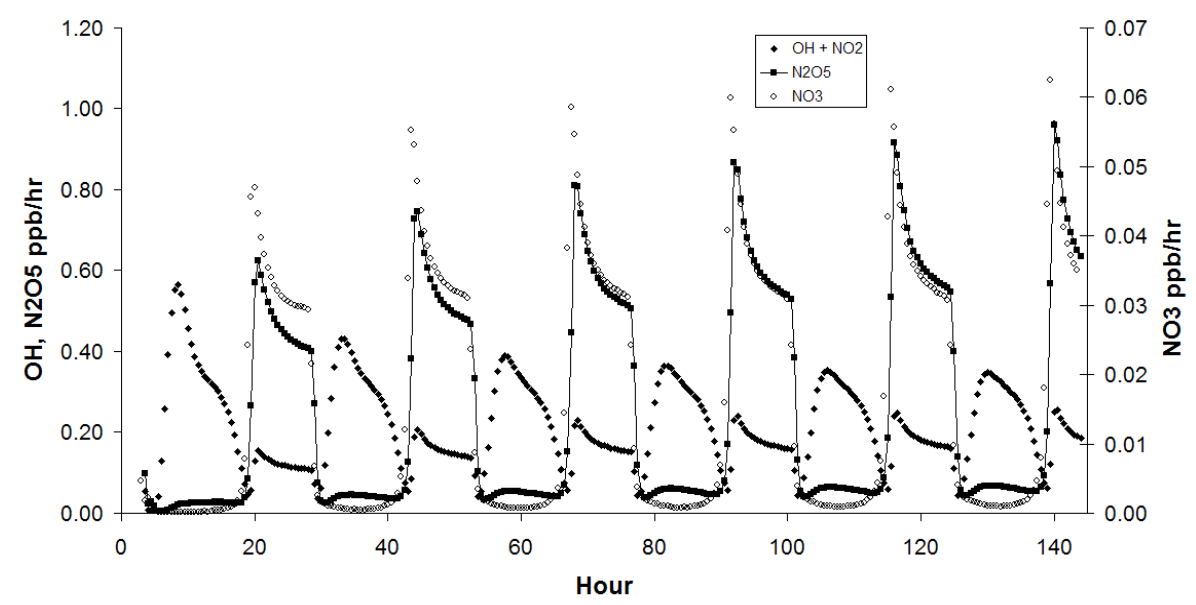

Fig. 2. $\mathrm{NO}_{3}^{-}$atm produced in $\mathrm{ppb} / \mathrm{hr}$ (using a fixed mixing height) by the three formation pathways. The $\beta$ pathway $(\mathrm{OH})$ dominates during the day while $\varepsilon(\mathrm{NO})$ is the main pathway at night with the $\chi$ pathway $\left(\mathrm{NO}_{3}\right)$ contributing only a few percent under these conditions (note the scale difference of $\chi$ on the secondary axis, which is used for clarity).

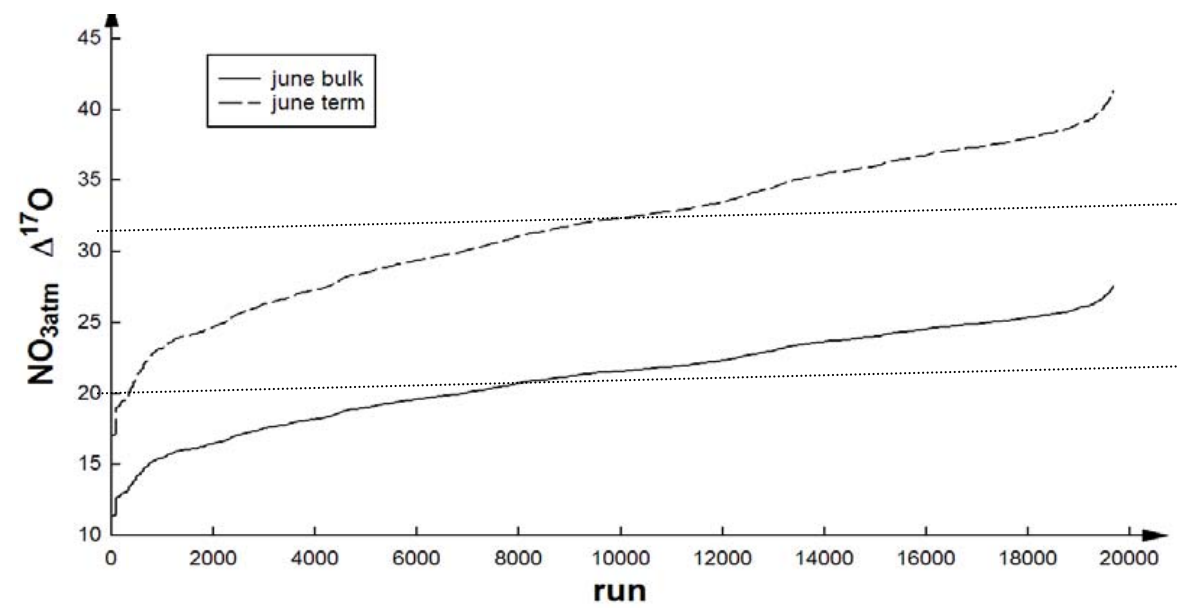

Fig. 3. Predicted $\Delta^{17} \mathrm{O}$ values for $\mathrm{NO}_{3}^{-}$atm for June at $35^{\circ} \mathrm{N}$ latitude using bulk and terminal atom transfer mechanisms. Range of observed mid-latitude $\mathrm{NO}_{3}^{-}$atm $\Delta^{17} \mathrm{O}$ values are bracketed by the dotted lines. Either transfer mechanism produces $\Delta^{17} \mathrm{O}$ that have not been observed due to the paucity of in situ data. 


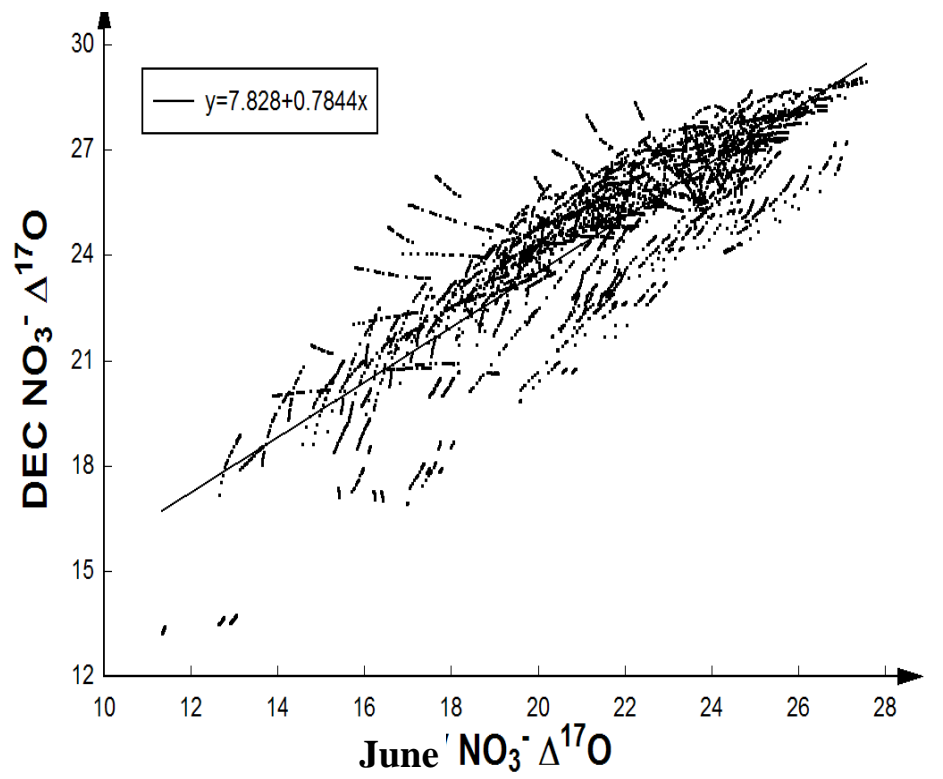

Fig. 4. The influence of photolysis on $\mathrm{NO}_{3}^{-}$atm $\Delta^{17} \mathrm{O}$ values are only $78 \%\left(r^{2}=.88\right)$ as high as those in December. Since all other parameters were varied the same in each run (temperature, trace gas, $\mathrm{RH}$, etc.) this difference is only due to change in $\mathrm{HNO}_{3}$ production driven by the seasonal difference photolysis lifetimes of $\mathrm{O}_{3}, \mathrm{NO}_{2}$ and $\mathrm{NO}_{3}$. values. Each point represents the $\Delta^{17} \mathrm{O}$ after a one week simulation. The June $\mathrm{NO}_{3 \text { atm }}^{-} \Delta^{17} \mathrm{O}$ values are only $78 \%\left(r^{2}=.88\right)$ as high as those in December. Since all other parameters were varied the same in each run (temperature, trace gas, $\mathrm{RH}$, etc.) this difference is only due to change in $\mathrm{HNO}_{3}$ production driven by the seasonal difference photolysis lifetimes of $\mathrm{O}_{3}, \mathrm{NO}_{2}$ and $\mathrm{NO}_{3}$.

\section{3}



Fig. 5. $\mathrm{Y}$-axis is the difference in $\Delta^{17} \mathrm{O}$ values of $\mathrm{NO}_{3}^{-}$atm produced (1 week simulation) using Scheme $C$ relative to Scheme $M(M-C$, red) and Scheme $D$ relative to Scheme $M(M-D$, black) all normalized to the $\Delta^{17} \mathrm{O}$ value produced using Scheme M (x-axis). 


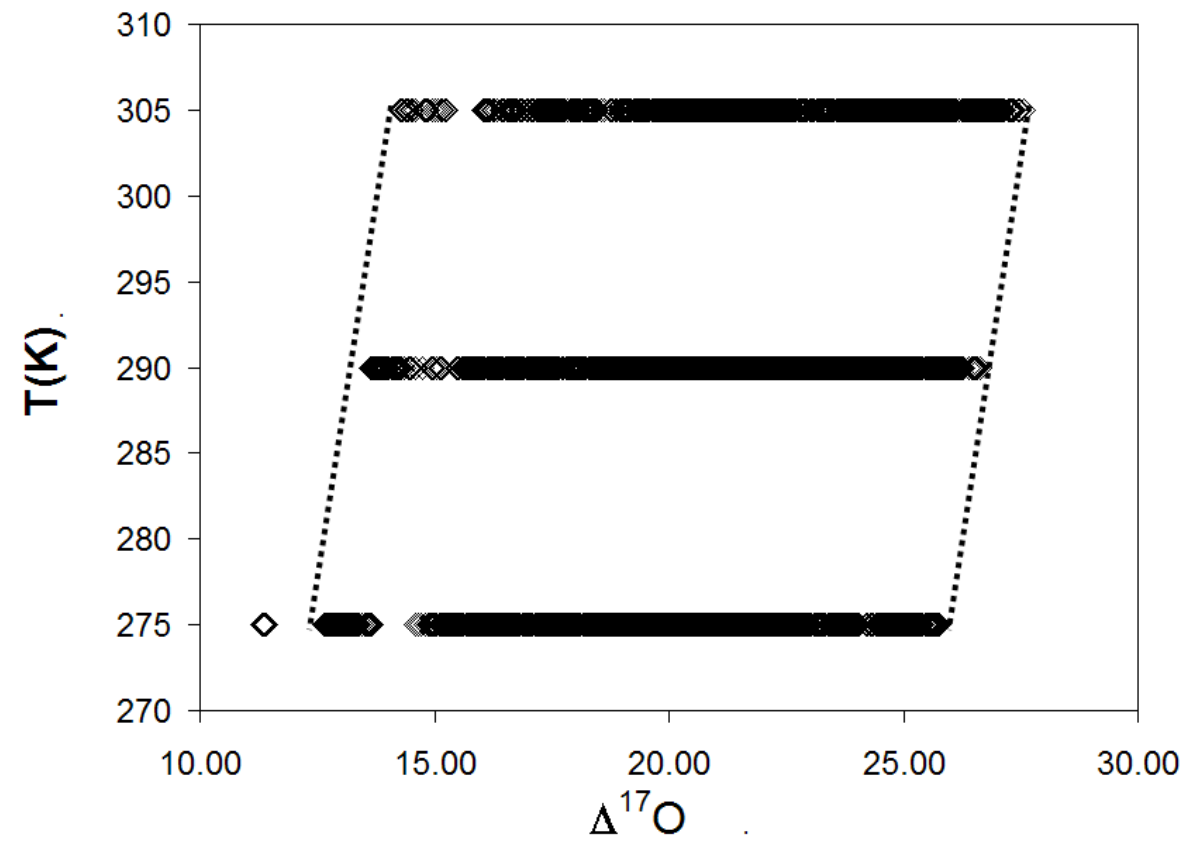

Fig. 6. Temperature dependant increases in $\mathrm{NO}_{3}^{-}$atm $\Delta^{17} \mathrm{O}$ values. Starting concentrations of $\mathrm{NO}_{\mathrm{x}}, \mathrm{O}_{3}, \mathrm{VOC}$, aerosol mass, and sulfate \% are all varied between high, medium, and low values (Table 1 ) while all other parameters are held constant. Dashed lines connect $\mathrm{NO}_{3}^{-} \mathrm{atm}$ $\Delta^{17} \mathrm{O}$ values with the same initial concentrations but different simulation temperatures. Slope of the dashed line is a measure of the strength of the temperature effect.



Fig. 7. Patterns and ranges of $\mathrm{NO}_{3}^{-}$atm $\Delta^{17} \mathrm{O}$ under radically different methane and carbon monoxide mixing ratios appears to be negligible. 


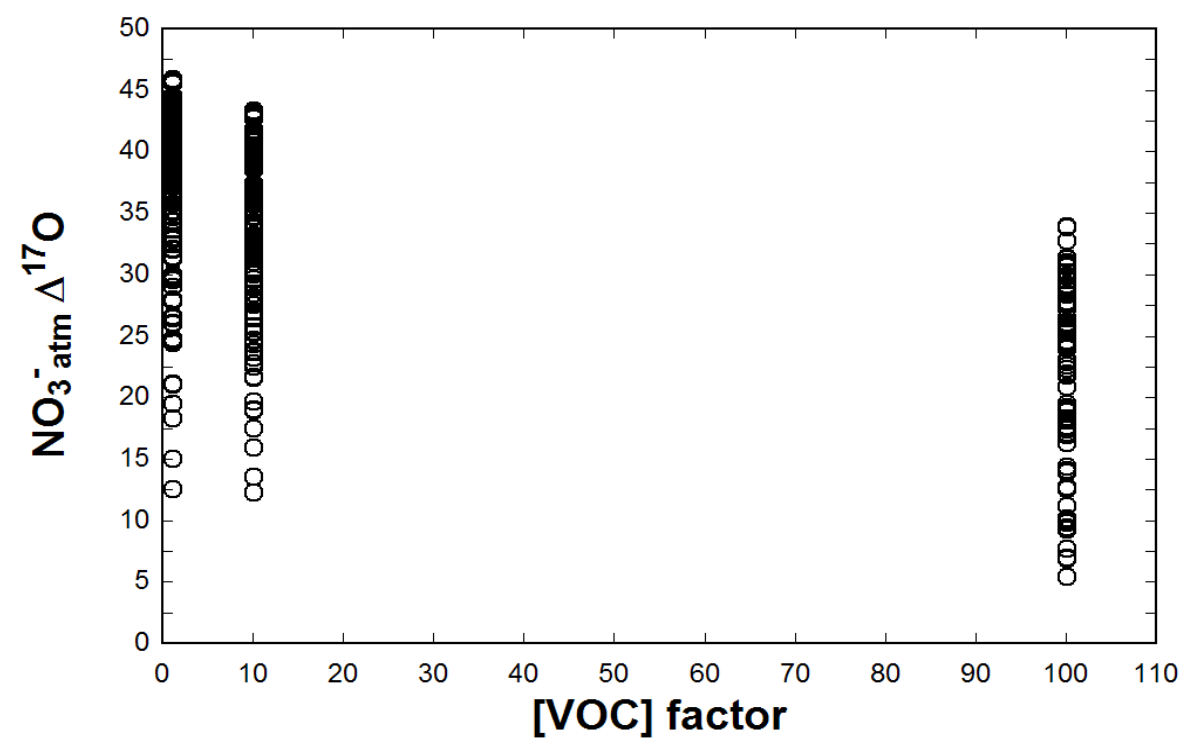

Fig. 8. $\mathrm{NO}_{3}^{-}$atm $\Delta^{17} \mathrm{O}$ values using December photolysis parameters and varying VOC mixing ratios. The VOC mixing ratio for any given simulation is determined by scaling the low VOC mixing ratio (Table 1) by the VOC factor $(1,10$, and 100). December photolysis generates and the terminal $\mathrm{O}_{3}$ mechanism generates high $\Delta^{17} \mathrm{O}$ values, relative to observations. High VOC mixing ratios combined with low $\mathrm{O}_{3}$ and $\mathrm{NO}_{\mathrm{x}}$ can suppress the $\Delta^{17} \mathrm{O}$ values to less than $10 \%$, but such conditions may not be atmospherically "realistic".

6867

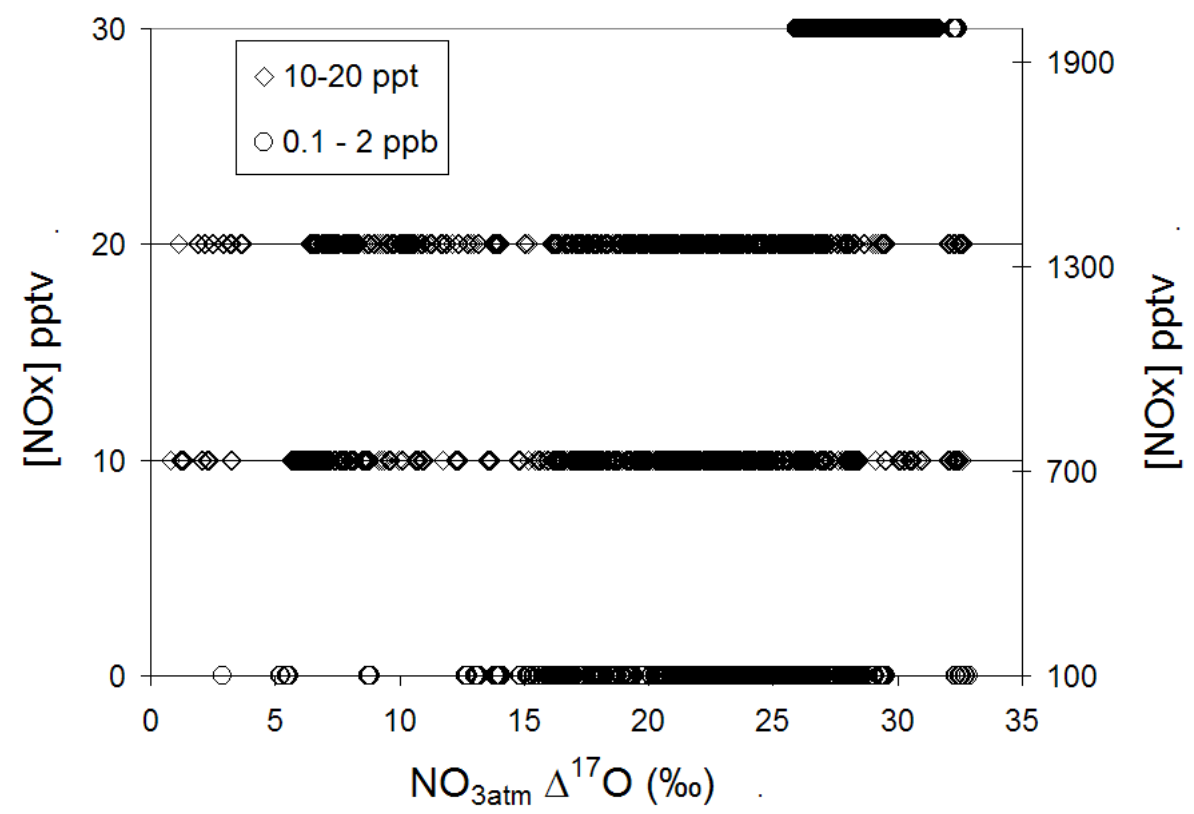

Fig. 9. Magnitude and range of $\mathrm{NO}_{3}^{-}$atm $\Delta^{17} \mathrm{O}$ values as a function of initial $\mathrm{NO}$ mixing ratios. 


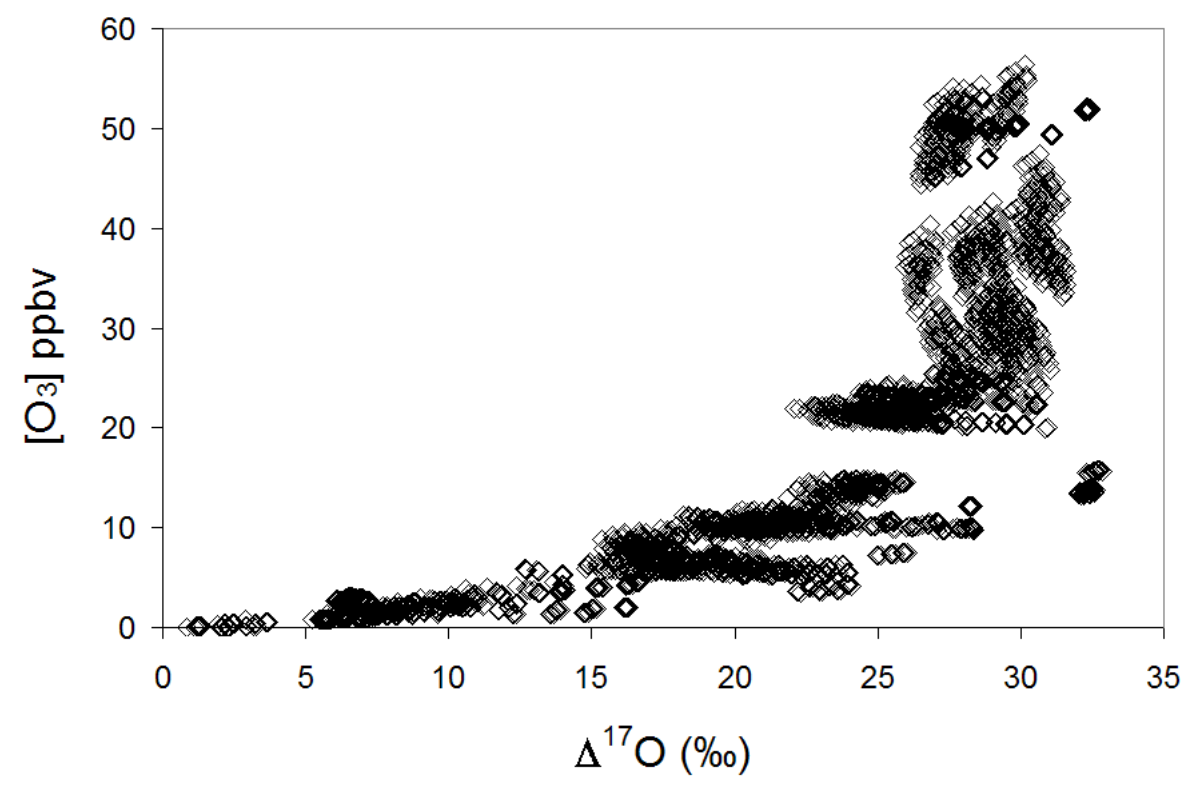

Fig. 10. $\mathrm{NO}_{3}^{-}$atm $\Delta^{17} \mathrm{O}$ values as a function of ending simulated $\mathrm{O}_{3}$ mixing ratios (initialized at $50,20,10$, and $1 \mathrm{ppbv})$. 